\title{
Iron budgets for three distinct biogeochemical sites around the Kerguelen Archipelago (Southern Ocean) during the natural fertilisation study, KEOPS-2
}

\author{
A. R. Bowie ${ }^{1,2,3}$, P. van der Merwe ${ }^{1}$, F. Quérouée ${ }^{1,2,3}$, T. Trull ${ }^{1,4}$, M. Fourquez ${ }^{2,5}$, F. Planchon ${ }^{3}$, G. Sarthou ${ }^{3}$, \\ F. Chever ${ }^{3, a}$, A. T. Townsend ${ }^{6}$, I. Obernosterer ${ }^{5}$, J.-B. Sallée ${ }^{7,8,9}$, and S. Blain ${ }^{5}$ \\ ${ }^{1}$ Antarctic Climate and Ecosystems Cooperative Research Centre (ACE CRC), Private Bag 80, Hobart, Tasmania 7001, \\ Australia \\ ${ }^{2}$ Institute for Marine and Antarctic Studies (IMAS), University of Tasmania, Private Bag 129, Hobart, Tasmania 7001, \\ Australia \\ ${ }^{3}$ Laboratoire des Sciences de l'Environnement Marin (LEMAR), UMR6539 UBO/CNRS/IRD/IFREMER, Institut \\ Universitaire Européen de la Mer (IUEM), Technopole Brest Iroise, 29280 Plouzané, France \\ ${ }^{4}$ CSIRO Marine and Atmospheric Research, Castray Esplanade, Hobart, Tasmania 7000, Australia \\ ${ }^{5}$ Université Pierre et Marie Curie, Laboratoire d'Océanographie Microbienne (LOMIC), UMR 7621 CNRS UPMC, Avenue \\ du Fontaulé, 66650 Banyuls sur mer, France \\ ${ }^{6}$ Central Science Laboratory (CSL), University of Tasmania, Private Bag 74, Hobart, Tasmania 7001, Australia \\ ${ }^{7}$ Sorbonne Universités, UPMC Univ., Paris 06, UMR 7159, LOCEAN-IPSL, 75005 Paris, France \\ ${ }^{8}$ CNRS, UMR 7159, LOCEAN-IPSL, 75005 Paris, France \\ ${ }^{9}$ British Antarctic Survey, High Cross, Cambridge CB3 0ET, UK \\ anow at: National Oceanography Centre, University of Southampton Waterfront Campus, European Way, \\ Southampton SO14 3ZH, UK
}

Correspondence to: A. R. Bowie (andrew.bowie@utas.edu.au)

Received: 19 November 2014 - Published in Biogeosciences Discuss.: 19 December 2014

Revised: 22 June 2015 - Accepted: 24 June 2015 - Published: 29 July 2015

\begin{abstract}
Iron availability in the Southern Ocean controls phytoplankton growth, community composition and the uptake of atmospheric $\mathrm{CO}_{2}$ by the biological pump. The KEOPS-2 (KErguelen Ocean and Plateau compared Study 2) "process study", took place around the Kerguelen Plateau in the Indian sector of the Southern Ocean. This is a region naturally fertilised with iron on the scale of hundreds to thousands of square kilometres, producing a mosaic of spring blooms which show distinct biological and biogeochemical responses to fertilisation. This paper presents biogeochemical iron budgets (incorporating vertical and lateral supply, internal cycling, and sinks) for three contrasting sites: an upstream high-nutrient low-chlorophyll reference, over the plateau and in the offshore plume east of the Kerguelen Islands. These budgets show that distinct regional environments driven by complex circulation and transport path-
\end{abstract}

ways are responsible for differences in the mode and strength of iron supply, with vertical supply dominant on the plateau and lateral supply dominant in the plume. Iron supply from "new" sources (diffusion, upwelling, entrainment, lateral advection, atmospheric dust) to the surface waters of the plume was double that above the plateau and 20 times greater than at the reference site, whilst iron demand (measured by cellular uptake) in the plume was similar to that above the plateau but 40 times greater than at the reference site. "Recycled" iron supply by bacterial regeneration and zooplankton grazing was a relatively minor component at all sites $(<8 \%$ of new supply), in contrast to earlier findings from other biogeochemical iron budgets in the Southern Ocean. Over the plateau, a particulate iron dissolution term of $2.5 \%$ was invoked to balance the budget; this approximately doubled the standing stock of dissolved iron in the mixed layer. The ex- 
change of iron between dissolved, biogenic particulate and lithogenic particulate pools was highly dynamic in time and space, resulting in a decoupling of the iron supply and carbon export and, importantly, controlling the efficiency of fertilisation.

\section{Introduction}

The concentration of carbon dioxide in earth's atmosphere, and therefore earth's climate, is highly sensitive to modification in the marine carbon (C) cycle due to the growth of phytoplankton in the Southern Ocean (Sarmiento and Gruber, 2006). These single-cell plants remove inorganic carbon from surface seawater during photosynthesis, and this inorganic carbon can be directly transferred into the deep sea when the plants die and sink, or indirectly through the food web. The Southern Ocean is responsible for $30 \%$ of global ocean carbon export (Schlitzer, 2002). As first demonstrated over 20 years ago, phytoplankton growth in the Southern Ocean is limited by the availability of the micronutrient trace element iron (Fe; Martin, 1990). Low dissolved iron (dFe) availability limits the annual uptake of atmospheric carbon dioxide $\left(\mathrm{CO}_{2}\right)$ by the Southern Ocean (Boyd et al., 2000), shapes phytoplankton species composition and physiology (Assmy et al., 2013), the cycling of other nutrient elements (Moore and Doney, 2007), and thus the structure of the entire marine ecosystem (Boyd and Ellwood, 2010).

Artificial mesoscale ocean iron fertilisation experiments have unequivocally demonstrated the role of $\mathrm{Fe}$ in setting phytoplankton productivity, biomass and community structure in high-nutrient low-chlorophyll (HNLC) regions (de Baar et al., 2005; Boyd et al., 2007). However, the "carbon sequestration efficiency" of ocean fertilisation as a means to sequester atmospheric $\mathrm{CO}_{2}$ (calculated as the additional (net) $\mathrm{C}$ that is exported from surface waters into the deep $(>1000 \mathrm{~m}$ ) ocean for a given addition of $\mathrm{Fe}$ ) varies widely between experiments and is considerably less than estimates from the early iron fertilisation experiments (see discussion in de Baar et al., 2008). This is due to a number of factors, including rapid grazing of phytoplankton in surface waters, the loss of added $\mathrm{Fe}$ by its precipitation and scavenging onto sinking particles, differences in estimated or assumed ironto-carbon $(\mathrm{Fe} / \mathrm{C})$ ratios of the cells, and changes in wind mixed layer depth.

The natural resupply of iron to Fe-depleted waters is a more efficient process (Blain et al., 2007), although in part this depends on the mode of Fe delivery (e.g. from above, laterally or from below) and on the ability of organic ligands to keep the supplied $\mathrm{Fe}$ in solution (Gerringa et al., 2008), and for continued ocean fertilisation, it is in part reliant on the concurrent supply of other major nutrients. In the Indian sector of the subantarctic Southern Ocean, natural Fe supply from the Kerguelen Plateau (Blain et al., 2007) and Crozet Islands (Pollard et al., 2009) results in increased phytoplankton biomass during summer, with chlorophyll levels increasing to more than 1 order of magnitude above the background, as revealed by NASA MODIS satellite chlorophyll climatology for January (2003-2010) (Westberry et al., 2013). Previous research on blooms in these localised "natural laboratories" has provided invaluable insights into mechanisms linking iron fertilisation and carbon cycling in the Southern Ocean, especially since studies of natural systems can address the effects of persistent, varying and multiple $\mathrm{Fe}$ sources that are not accessible through deliberate artificial mesoscale fertilisation experiments.

The KEOPS-1 (KErguelen: Ocean and Plateau compared Study 1) project, which took place in the late austral summer of January-February 2005, demonstrated that this natural fertilisation of the Southern Ocean resulted in dramatic changes in the functioning of the ecosystem with large impacts on marine biogeochemical cycles (Blain et al., 2007, 2008a). These observations of the bloom were largely confined to the plateau region, where vertical upwelled supply from the plateau sediments (Blain et al., 2008b; Zhou et al., 2014) and lateral advection of water that had been in contact with the continental shelf of Heard Island to the south (Chever et al., 2010) were the dominant sources of dissolved and particulate $\mathrm{Fe}$ (as confirmed using rare earth element (REE) and radium (Ra) isotope tracers; van Beek et al., 2008; Zhang et al., 2008). The interaction of waters, islands and plateau of the Kerguelen Archipelago with several circumpolar fronts of the Southern Ocean allowed us to make a first attempt at placing our regional KEOPS-1 observations within a broader basin-scale context (Blain et al., 2007).

The KEOPS-2 project was designed to improve the spatial and temporal coverage of the Kerguelen region. During KEOPS-2, which was approved as a GEOTRACES process study $^{1}$, we studied the region above and downstream of the plateau and observed a massive natural iron fertilisation on the scale of hundreds of thousands of square kilometres. This produced a patchwork of blooms with diverse biological and biogeochemical responses, as detailed in the multiple studies in this special issue of Biogeosciences (volumes 11-12). KEOPS-2 was also carried out in the austral spring to document the early stages of the bloom and to complement the results of KEOPS- 1 obtained in late summer during the start of the decline of the bloom, with a principal aim to better constrain the mechanism of Fe supply to surface waters earlier in the season.

Since $\mathrm{Fe}$ is actively taken up into phytoplankton and transferred throughout the food web, including removal by particle settling and remineralisation in deep waters, the assessment of its availability is quite complex and cannot be judged from $\mathrm{dFe}$ levels in surface waters alone (Breitbarth et al., 2010). Advances in chemical oceanographic techniques for trace elements through the GEOTRACES program (SCOR

\footnotetext{
${ }^{1}$ http://www.geotraces.org/cruises/cruise-summary/68-science/ process-studies/206-geotraces-process-studies
} 
Working Group, 2007) now allow the measurement of $\mathrm{Fe}$ associated with different phases (dissolved and particulate), internal biological recycling and $\mathrm{Fe}$ export from surface waters. The results from earlier iron biogeochemical budgets for FeCycle-I (Boyd et al., 2005; Frew et al., 2006), KEOPS-1 (Blain et al., 2007; Chever et al., 2010), CROZEX (CROZet natural iron bloom and EXport experiment; Planquette et al., 2007, 2009) and SAZ-Sense (Sensitivity of the subantarctic zone to environmental change; Bowie et al., 2009) have highlighted that the dominant "new" Fe fluxes are associated with the particulate phase. Particles thus represent an important transport vector for trace metals in the marine ecosystem, although their bioavailability or transfer into a bioavailable fraction remains uncertain. Suspended particles have also been shown to be important aspects of sedimentary, boundary layer Fe sources and export processes (Tagliabue et al. 2009; Homoky et al., 2013; Marsay et al., 2014; Wadley et al., 2014), with particles being transported laterally over hundreds of kilometres in the ocean (Lam et al., 2006; Lam and Bishop, 2008). The biological cycling of particulate Fe may therefore be the most important aspect of the complete $\mathrm{Fe}$ biogeochemical cycle, especially since earlier budgets have demonstrated that biological Fe "demand" cannot be satisfied by the new Fe supply (Boyd et al., 2005; Blain et al., 2007; Sarthou et al., 2008; Bowie et al., 2009; de Jong et al., 2012). A simple one-dimensional vertical model that correctly represented the input of $\mathrm{dFe}$ to surface waters during KEOPS-1 did not accurately represent the supply of other geochemical tracers or particulate Fe (Blain et al., 2007; van Beek et al., 2008; Zhang et al., 2008), and the role of dissolved and particulate Fe earlier in the season (winter stock) in the Kerguelen region has yet to be quantified.

This paper presents a short-term (days to weeks) Fe budget for the period of KEOPS-2 for each of three process sites: (i) a "plateau" bloom site (A3) on the central Kerguelen Plateau studied during late summer on KEOPS-1 and reoccupied during spring on KEOPS-2; (ii) a "plume" bloom site (E) east of the Kerguelen Islands, which was located within a quasistationary, bathymetrically trapped recirculation feature near the polar front (PF); and (iii) a "reference" site (R-2) south of the PF and upstream (southwest) of the Kerguelen Islands in HNLC waters. We focus on mixed-layer integrated pools of dissolved $\mathrm{Fe}$ and particulate $\mathrm{Fe}$ (which we further separate into biogenic and lithogenic fractions using elemental normalisers), estimate the fluxes of Fe associated with new and recycled Fe sources, and compare Fe supply and demand with implications for bloom duration and magnitude. Our observations also include particulate measurements in both suspended-water-column (in situ pump; ISP) and sinkingexport (free-floating sediment trap; "P-trap") particles below the mixed layer, with linkage to food web processes via a discussion of $\mathrm{Fe} / \mathrm{C}$ ratios. Finally, we present a seasonal comparison of our springtime budget for KEOPS-2 with late summer observations from KEOPS-1 and also make comparison with findings from other sectors of the Southern Ocean subjected to natural Fe fertilisation (e.g. Frew et al., 2006 and Boyd et al., 2005 for FeCycle-I, and Ellwood et al., 2014 for FeCycle-II east of New Zealand; Bowie et al., 2009 for SAZ-Sense south of Tasmania; Planquette et al., 2011 for CROZEX near the Crozet Islands; and Zhou et al., 2010 for Blue Water Zone near the western Antarctic Peninsula). The observations of dFe (Quéroué et al., 2015) and particulate trace metals (van der Merwe et al., 2015) are detailed in companion papers in this special issue to allow the current paper to focus explicitly on the construction of iron budgets; however, the three papers should be seen as a collective whole.

\section{Material and methods}

\subsection{Study area}

The KEOPS-2 (KErguelen Ocean and Plateau in compared Study 2) expedition was carried out in the Indian sector of the Southern Ocean in the vicinity of the Kerguelen Plateau between 7 October and 30 November 2011 on the RV Marion Dufresne (Fig. 1a). The plateau of the Kerguelen Archipelago is a northwest-southeast seafloor feature approximately $500 \mathrm{~m}$ deep and is constrained by the Kerguelen Islands to the north and the smaller volcanic Heard and McDonald islands to the south. Our study was conducted in early austral spring when phytoplankton biomass was developing rapidly and forming a mosaic of phytoplankton blooms in the region (Trull et al., 2015; Lasbleiz et al., 2014). Since sampling at the different stations took place at different times over the $\sim 7$-week study, our observations also provide a temporal sequence relative to the development of surface biomass.

The Kerguelen bloom has two main features: a northern branch that extends northeast of the island into waters both south and north of the PF and a larger bloom covering $\sim 45000 \mathrm{~km}^{2}$ south of the PF and largely constrained to the shallow bathymetry of the Kerguelen Plateau $(<700 \mathrm{~m})$ (Mongin et al., 2008; Supplement in Trull et al., 2015) (Figs. 1b and 2). Thirty-two stations were sampled during KEOPS-2, often with repeat visits. Here, we focus on three study sites, namely plateau A3, plume E and reference R-2 (Fig. 1). Two visits were made to $\mathrm{A} 3$ at the start (A3-1) and end (A3-2) of the voyage (28 days apart), and five visits were made to site $\mathrm{E}$ (over 21 days) to document the bloom development. Based on the trajectories of surface drifters, stations E-1, E-3 and E-5 were taken as tracking the middle of a recirculation region (d'Ovidio et al., 2015), so that they can be considered as pseudo-Lagrangian and their succession in time can be considered a first-order time series. Full details of other stations and sampling designed to document the meridional and zonal extensions of the blooms on the plateau and to the east of the Kerguelen Islands are contained in companion papers in this special issue of Biogeosciences. 

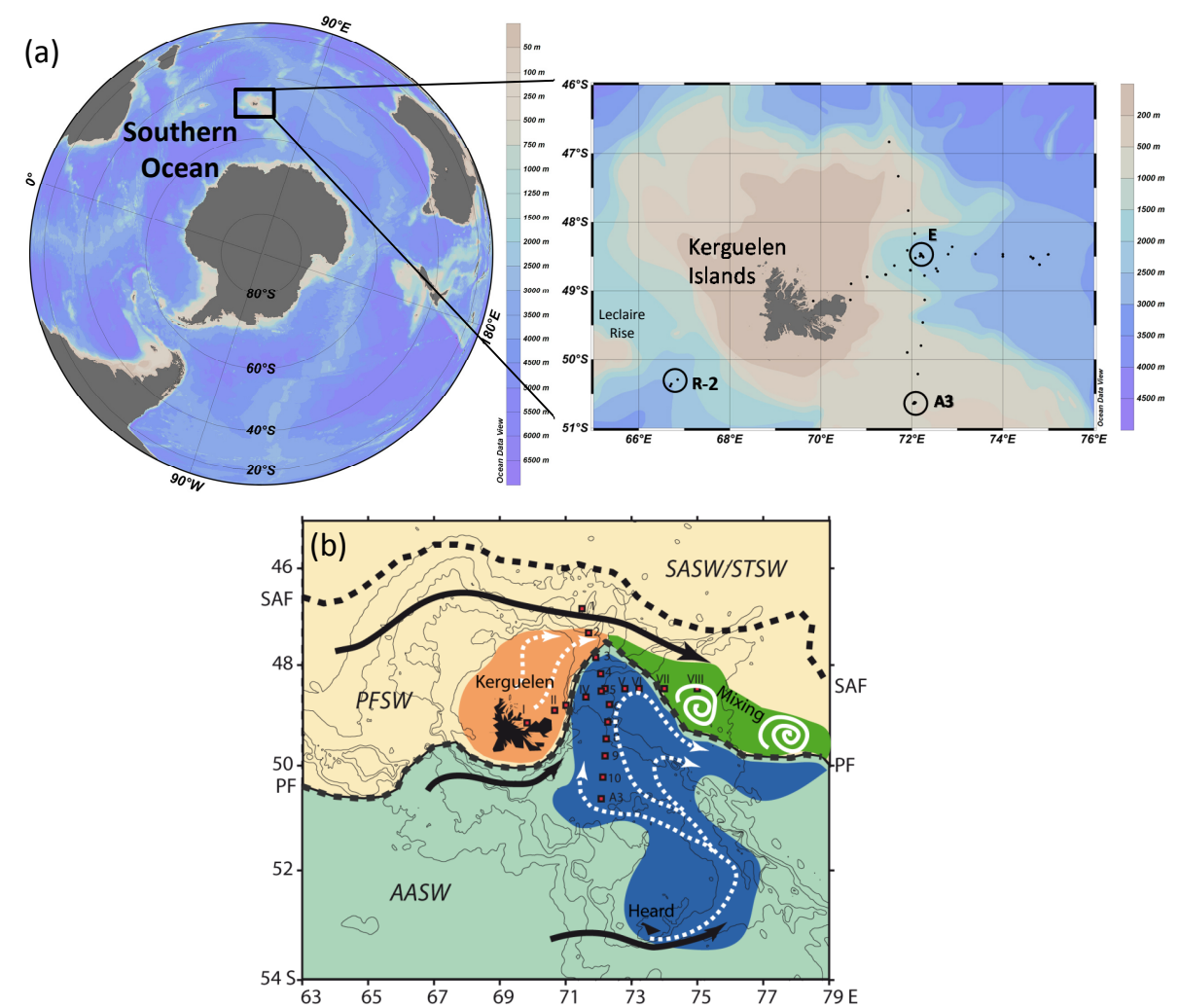

Figure 1. (a) The location of KEOPS-2 in the Indian sector of the Southern Ocean, showing bathymetry around the Kerguelen Archipelago. Our biogeochemical iron budgets focus on three process stations (open black circles): reference R-2 $\left(50^{\circ} 2^{\prime} \mathrm{S}, 66^{\circ} 4^{\prime} \mathrm{E}\right)$, plateau A3 $\left(50^{\circ} 4^{\prime} \mathrm{S}\right.$, $\left.72^{\circ} 0^{\prime} \mathrm{E}\right)$ and plume $\mathrm{E}\left(48^{\circ} 3^{\prime} \mathrm{S}, 72^{\circ} 1^{\prime} \mathrm{E}\right)$. Black dots mark the positions of the other stations visited, including N-S and E-W survey transects at the start of the KEOPS-2 expedition. (b) A schematic of the mean regional circulation of surface and subsurface waters around the Kerguelen Archipelago, indicating circumpolar Southern Ocean fronts, locations of stations along N-S and E-W transects, and pathways and origins of different water masses flowing on the plateau and offshore into the plume. The abbreviations are Antarctic Surface Water (AASW), Polar Front Surface Water (PFSW), Subantarctic Surface Water (SASW), Subtropical Surface Water (STSW), Subantarctic Front (SAF) and the polar front (PF) (reproduced with permission from Park et al. (2014a), courtesy of Isabelle Durand and Young-Hyang Park, LOCEAN/DMPA, MNHN, Paris).
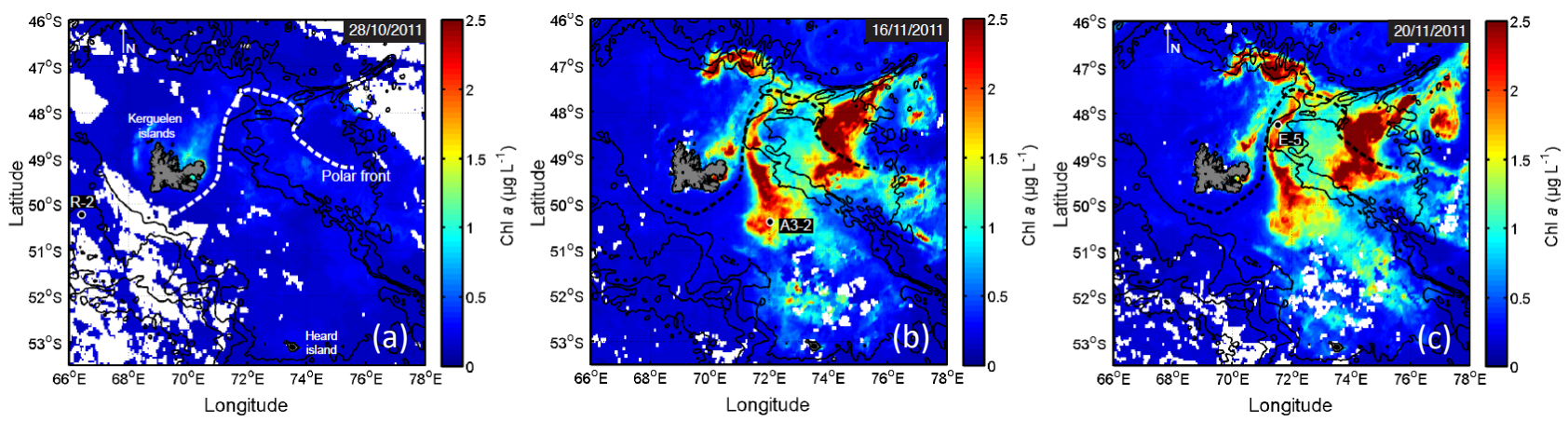

Figure 2. MODIS ocean-colour satellite images showing the development of the plateau and plume blooms during KEOPS-2. Surface chlorophyll $\left(\mu \mathrm{g} \mathrm{L}^{-1}\right)$ biomass is shown for the nearest clear sky day to the final sampling day at stations R-2 (a), A3-2 (b) and E-5 (c). The $\mathrm{PF}$ is shown as a black dashed line in (b) and (c). Trull et al. (2015) discuss the timing of the stations relative to bloom development.

The hydrology and circulation around and above the Kerguelen Plateau have been described by Park et al. (2008a, b, 2014a), van Beek et al. (2008), Zhang et al. (2008) and
Zhou et al. (2014). The mean circulation is shown in Fig. 1b. Briefly, the Kerguelen Plateau constitutes a barrier to the eastward flowing Antarctic Circumpolar Current (ACC), the 
main jets of which are the Subantarctic Front (SAF) and PF. Most of the ACC is deflected north of the Kerguelen Islands as Subantarctic Surface Water (SASW) but some filaments pass between the Kerguelen Islands and Heard Island (as the PF) and further south between Heard Island and Antarctica (Roquet et al., 2009). Above the plateau, the remainder of the ACC comes from the western part of the plateau. Currents of AASW travelling along the western flank of the plateau are deflected south and east of Heard Island as a branch of the Fawn Trough Current (FTC) (Sokolov and Rintoul, 2009) before travelling in a broadly northwest direction up along the eastern shelf break. The water flow is then deflected toward the east of the Kerguelen Islands, where there is an intense mixing zone consisting of mesoscale eddies which travel many thousands of kilometres in the ACC towards the Australian sector of the Southern Ocean.

\subsection{Sampling}

All trace metal sampling and analytical procedures followed recommended protocols in the cookbook ${ }^{2}$ published by the international program GEOTRACES (Bishop et al., 2012; Cutter and Bruland, 2012; Planquette and Sherrell, 2012). All methods have been successfully used previously by this team during the KEOPS-1 (Blain et al., 2008b) and SAZSense projects (Bowie et al., 2009). Subtle differences in methods employed during the earlier KEOPS-1 and SAZSense projects are described in those papers and/or later in this manuscript.

\subsubsection{Trace metal rosette (TMR)}

Water column samples were collected using $10 \mathrm{~L}$ externally closing, Teflon-lined Niskin-1010X bottles deployed on an autonomous 1018 intelligent rosette system (TMR - trace metal rosette, specially adapted for trace metal work; General Oceanics Inc.). The polyurethane-powder-coated aluminium rosette frame was suspended on Kevlar rope which passed through a clean block with a plastic sheave (General Oceanics) and was lowered to a maximum depth of $1300 \mathrm{~m}$. Bottles were tripped at preprogrammed depths using a pressure sensor as the TMR was being raised through the water column at approximately $0.5 \mathrm{~m} \mathrm{~s}^{-1}$.

All sample processing was carried out under an ISO class5 trace metal clean laminar flow bench in a HEPA filteredair clean container, with all materials used for sample handling thoroughly acid-washed. Samples were drawn through C-Flex tubing (Cole Parmer) and filtered in-line through $0.2 \mu \mathrm{m}$ pore size acid-washed capsules (Pall Supor membrane Acropak 200 or Sartorius Sartobran 300 filters). The dissolved fraction is thus likely to contain colloids and small particles $<0.2 \mu \mathrm{m}$ in diameter (Bowie and Lohan, 2009). All transfer tubes, filtering devices and sample containers

\footnotetext{
${ }^{2}$ http://www.geotraces.org/libraries/documents/Intercalibration/ Cookbook.pdf
}

were rinsed liberally with sample before final collection in $125 \mathrm{~mL}$ Nalgene LDPE bottles. Seawater samples were acidified within $24 \mathrm{~h}$ of collection using $2 \mathrm{~mL}$ of concentrated ultrapure hydrochloric acid $(\mathrm{HCl}$, Seastar BASELINE grade) per litre of sample, resulting in an approximate final $\mathrm{pH}$ of 1.8 , double bagged and stored for at least $24 \mathrm{~h}$ at ambient temperature until analysis.

\subsubsection{In situ pumps (ISPs)}

Suspended particles for trace elemental analysis were collected using 11 large-volume in situ pumps (McLane Research Laboratories WTS6-1-142LV and Challenger Oceanics pumps), suspended simultaneously at prechosen depths following methods reported in Bowie et al. (2009). Up to $2000 \mathrm{~L}$ of seawater was filtered across a $142 \mathrm{~mm}$ diameter stack (134 mm diameter active area) consisting of a $53 \mu \mathrm{m}$ nylon pre-filter screen (NYTEX) followed by a QMA quartz fibre filter $(1 \mu \mathrm{m}$ nominal pore size; Sartorius). The QMA filter was supported by a $350 \mu \mathrm{m}$ polyester mesh, which was placed on top of the Teflon PFA grid of the pump housing. Prior to use, NYTEX screens were conditioned by soaking in $5 \% \mathrm{H}_{2} \mathrm{SO}_{4}$, rinsed $3 \times$ with Milli-Q-grade water, dried at ambient temperature under a laminar flow hood and stored in clean plastic Ziploc ${ }^{\circledR}$ bags. QMA filters were conditioned for trace metal analysis (precombustion and acid cleaning) following Bowie et al. (2010). Upon recovery of the pumps, subsamples were taken from the QMA filters by using a circular plastic punch ( $14 \mathrm{~mm}$ diameter) and by cutting the nylon mesh using ceramic scissors. Filters were dried under a laminar flow bench and stored at $-18^{\circ} \mathrm{C}$ in acid-washed PCR trays until further analysis in the home laboratory. The $1-53$ and $>53 \mu \mathrm{m}$ size fractions were digested and analysed separately, and the particulate iron ( $\mathrm{pFe}$ ) reported here is the sum of both fractions. The ISPs were shown to be efficient in capturing large $(>53 \mu \mathrm{m})$ particles (Planchon et al., 2015).

\subsubsection{Free-floating traps (P-trap)}

Sinking particles for trace elemental analysis were collected using PPS3/3 free-floating sediment traps (Technicap, France), specially adapted for trace metals and deployed at $200 \mathrm{~m}$. Traps were deployed for 5.3, 5.1, 1.9 and 1.5 days at stations E-1, E-3, A3-2 and E-5, respectively. The trap deployed at station R-2 was lost and not recovered. Traps drifted between 10 and $43 \mathrm{~km}$ over the course of the deployment. Full details of the trap deployments are given in Laurenceau-Cornec et al. (2015) and Planchon et al. (2015). Samples for trace elemental analysis were collected in three separate acid-washed cups (specifically for trace metals) containing a low trace metal brine solution (salinity $\sim 60$ ), each opened for either $1,3,8$ or $12 \mathrm{~h}$ (depending on the station). Upon recovery, cups were taken to a clean room and particles filtered off-line onto a $47 \mathrm{~mm}$ diameter, $2 \mu \mathrm{m}$ porosity polycarbonate filter under gentle vacuum using a Teflon PFA unit 
(Savillex Corp., USA) equipped with a $350 \mu \mathrm{m}$ pre-screen (to exclude zooplankton).

\subsection{Analysis}

\subsubsection{Dissolved iron}

Dissolved $\mathrm{Fe}(\mathrm{dFe})$ was determined shipboard by flow injection analysis with chemiluminescence detection (FI-CL) using in-line preconcentration on an 8-hydroxyquinoline chelating resin (adapted from Obata et al., 1993, de Jong et al., 1998 and Sarthou et al., 2003). Dissolved Fe data were quality controlled against the SAFe (Sampling and Analysis of Fe) standard reference materials (Johnson et al., 2007). Full data including certification results and analytical figures of merit are reported in Quéroué et al. (2015).

\subsubsection{Particulate iron}

Particulate $\mathrm{Fe}(\mathrm{pFe})$ was determined as follows. Sampled particles were acid extracted in $1 \mathrm{~mL}$ concentrated $\mathrm{HNO}_{3}$ (Seastar Baseline) for $12 \mathrm{~h}$ on a DigiPREP HP Teflon hotplate supplied with HEPA-filtered air (SCP Science) at $120^{\circ} \mathrm{C}$ using $15 \mathrm{~mL}$ Teflon PFA Savillex vials. Digest solutions were diluted with $10 \mathrm{~mL}$ ultra high-purity water to $10 \% \mathrm{HNO}_{3}$ and spiked with $10 \mathrm{ppb}$ indium as internal standard prior to analysis by sector field inductively coupled plasma mass spectrometry (Finnigan ELEMENT 2, Thermo Scientific), following Bowie et al. (2010). Blanks from replicate analysis of filters treated identically to the sample filters but without large volumes of seawater passed through them, were typically $2-3 \%$ and $<1 \%$ of the pFe sample concentrations for the ISP deployments and P-trap deployments, respectively. Recoveries from the analysis of the Community Bureau of Reference plankton certified reference material BCR-414 were excellent, with a $101 \%$ recovery $(n=3)$ for $\mathrm{pFe}$. Full data are reported in van der Merwe et al. (2015).

\subsubsection{Particulate organic carbon and nitrogen}

For particulate organic carbon (POC) and particulate nitrogen (PN) analyses, QMA quartz filters from the ISPs were subsampled in a flow bench using a $14 \mathrm{~mm}$ diameter plastic punch and transferred to silver foil cups (Sercon brand $p / n$ SC0037). Samples were also collected from the P-traps for POC and PN analyses (see Laurenceau-Cornec et al., 2015). Samples were treated with a $40 \mu \mathrm{L}$ aliquot of $2 \mathrm{~N} \mathrm{HCl}$ to remove carbonates (King et al., 1998), dried at $60^{\circ} \mathrm{C}$ for $48 \mathrm{~h}$ and stored in a desiccator until analysis using a ThermoFinnigan Flash EA1112 elemental analyzer (using sulfanilamide standards) at the Central Science Laboratory, University of Tasmania. The $>53 \mu \mathrm{m}$ fraction was treated in the same way at the Vrije Universiteit Brussel after first transferring the material from one fourth of the screen, using prefiltered seawater, onto $25 \mathrm{~mm}$ diameter, $1.0 \mu \mathrm{m}$ pore size silver membrane filters (Sterlitech, Concord). Blank corrections for the pump samples were estimated from filters prepared identically but not deployed on the ISPs; for the trap samples this was done by re-filtering the pre-filtered seawater. All blank corrections were less than $2 \%$ for all samples. The subsampling introduces uncertainties of 5-10\% from inhomogeneous filter coverage that exceeds the analytical uncertainty of $\sim 1 \%$ in the POC analysis (Trull et al., 2015).

\subsection{Biological iron cycling}

\subsubsection{Iron uptake}

Trace metal clean seawater was collected from the mixed layer $(20-40 \mathrm{~m})$ using the TMR, was transferred into acidwashed polycarbonate bottles and $0.2 \mathrm{nmol} \mathrm{L}^{-1}$ (final concentration) of enriched ${ }^{55} \mathrm{Fe}$ as $\mathrm{FeCl}_{3}$ was added $\left(1.83 \times 10^{3}\right.$ $\mathrm{Ci} \mathrm{mol}^{-1}$ of specific activity, Perkin Elmer). Bottles were placed at in situ temperature in on-deck incubators continuously fed by surface seawater. Incubations were conducted for $24 \mathrm{~h}$ (sunrise to sunrise) at several light intensity levels $(75,45,25,16,4$ and $1 \%$ of photosynthetically active radiation; PAR). For stations R-2, A3-1, E-1 and E-3, seawater was prefiltered on a $25 \mu \mathrm{m}$ mesh size before ${ }^{55} \mathrm{Fe}$ was added. After incubation, $300 \mathrm{~mL}$ of seawater was passed through $0.2 \mu \mathrm{m}$ pore size nitrocellulose filters $(47 \mathrm{~mm}$ diameter, $\mathrm{Nu}-$ clepore). To determine intracellular Fe uptake rates, ${ }^{55} \mathrm{Fe}$ not incorporated by cells was removed immediately after filtration using $6 \mathrm{~mL}$ of a Ti-citrate-EDTA washing solution for $2 \mathrm{~min}$, then rinsed three times with $5 \mathrm{~mL}$ of $0.2 \mu \mathrm{m}$ filtered seawater for $1 \mathrm{~min}$ (Hudson and Morel, 1989; Tang and Morel, 2006). The filters were placed into plastic vials and $10 \mathrm{~mL}$ of the scintillation cocktail "Filtercount" (Perkin Elmer) added. Vials were agitated for $24 \mathrm{~h}$ before the radioactivity on filters was counted with the Tricarb ${ }^{\circledR}$ scintillation counter (precision $<10 \%$ ). Controls were obtained with $300 \mathrm{~mL}$ of microwave-sterilised seawater ( $750 \mathrm{~W}$ for $5 \mathrm{~min}$ ) incubated and treated the same way. Subsamples for enumeration by flow cytometry were collected from each bottle just before the filtration step. Cells were fixed in glutaraldehyde $(1 \%)$ and kept frozen $\left(-80^{\circ} \mathrm{C}\right)$ until processing and analysis. Data were corrected by blank subtraction and Fe uptake rates normalised to the concentration of $\mathrm{Fe}$ in each incubation (in situ $\mathrm{dFe}$ and ${ }^{55} \mathrm{Fe}$ added). Further details are given in Fourquez et al. (2015).

\subsubsection{Iron remineralisation}

Since iron regeneration was not measured directly by experiment during KEOPS-2, we used the following approach to calculate iron regeneration fluxes. Bacterial Fe regeneration was estimated from bacterial turnover times determined from bacterial production and biomass (Christaki et al., 2014), assuming all loss of bacterial biomass through viral lysis and flagellate grazing resulted in the regeneration of Fe (Strzepek et al., 2005) and using a bacterial iron quota of $7.5 \mu \mathrm{mol}$ 
$\mathrm{Fe}(\mathrm{mol} \mathrm{C})^{-1}$ (Tortell et al. 1996). The mesozooplankton grazing contribution to $\mathrm{Fe}$ regeneration was assumed to be equal to the experimentally determined $\mathrm{Fe}$ regeneration during KEOPS-1 (Sarthou et al., 2008). The regeneration rates per mesozooplankton individual determined in Sarthou et al. (2008), were then multiplied by mesozooplankton abundance, calculated from the number of cells captured in a daily haul over $200 \mathrm{~m}$ during KEOPS-2 (Carlotti et al., 2015; values reported in Table 6 in Laurenceau-Cornec et al., 2015).

\section{Results and discussion}

\subsection{Biogeochemical settings at our three study sites}

Full descriptions of the $\mathrm{dFe}$ and $\mathrm{pFe}$ distributions can be found in Quéroué et al. (2015) and van der Merwe et al. (2015), respectively, with further presentation of the distributions of other micronutrient trace elements $(\mathrm{Mn}, \mathrm{Co}, \mathrm{Ni}$, $\mathrm{Cu}, \mathrm{Cd}, \mathrm{Pb}$ ) from KEOPS-2 to be presented elsewhere. However, briefly our subset of stations used for the iron budgets can be described as follows.

\subsubsection{Reference station R-2}

In the upper $100 \mathrm{~m}$, we observed a salinity minimum (33.8) and temperature maximum $\left(2.2^{\circ} \mathrm{C}\right)$ characteristic of Antarctic Surface Water (AASW) overlying a layer of winter water (WW) at $180-200 \mathrm{~m}\left(T_{\min }\right.$ of $\left.1.6^{\circ} \mathrm{C}\right)$ (Fig. 3a). Deeper in the water column, a $T_{\max }$ of $2.5^{\circ} \mathrm{C}$ at $500 \mathrm{~m}$ (associated with an oxygen minimum; not shown) was indicative of upper Circumpolar Deep Water (UCDW) overlying a salinity maximum of 34.8 at $1830 \mathrm{~m}$ in lower Circumpolar Deep Water (LCDW). Phytoplankton abundance was low $(0.2 \mu \mathrm{g}$ Chl $a \mathrm{~L}^{-1}$; Lasbleiz et al., 2014) and dominated by diatoms, in waters with relatively high surface nitrate concentrations ( $>25 \mu \mathrm{mol} \mathrm{L}{ }^{-1}$; Blain et al., 2015), typical of Southern Ocean HNLC conditions (Lasbleiz et al., 2014).

Dissolved Fe concentrations were very low at the surface $\left(<0.1 \mathrm{nmol} \mathrm{L}^{-1}\right)$ and increased with depth, averaging $0.3 \mathrm{nmol} \mathrm{L}^{-1}$ in LCDW and broadly tracking the nitrate profile. The pFe profile showed a similar structure to the $\mathrm{dFe}$ profile but with surface and deep water concentrations between 0.3 and $1.1 \mathrm{nmol} \mathrm{L}^{-1}$ (the deepest sample was $148 \mathrm{~m}$ above the seafloor). The exception was at $500 \mathrm{~m}$, where, interestingly, we observed a $\mathrm{dFe}$ and $\mathrm{pFe}$ peak of 0.4 and $1.6 \mathrm{nmol} \mathrm{L}^{-1}$, respectively. Whilst this maximum may have arisen due to the enrichment of Fe in UCDW delivered from further south, we hypothesise that the Fe supply may have originated from subsurface sediments of the nearby Leclaire Rise (also known as Skiff Bank; Kieffer et al., 2002), a large seamount which rises to $250 \mathrm{~m}$ at $49^{\circ} 50^{\prime} \mathrm{S}, 65^{\circ} 00^{\prime} \mathrm{E}$ (approximately $140 \mathrm{~km}$ northwest of station R-2). Similar lithogenic inputs were also observed for other dissolved (Mn; F. Quéroué, personal communication, 2014, data not shown) and particulate (Mn, Al; van der Merwe et al., 2015) trace elements.

The $\mathrm{dFe}$ profile at the KEOPS- 2 reference station R-2 is similar to the KEOPS-1 reference station C11 (with the exception of the R-2 enrichment in the 200-700 m depth strata; Fig. 4a), but it should be noted that the location of C11 was quite different - in HNLC waters to the southeast of the Kerguelen Plateau (51 $\left.{ }^{\circ} 39^{\prime} \mathrm{S}, 78^{\circ} 00^{\prime} \mathrm{E}\right)$ - and we had only $1 \mathrm{dFe}$ data point in UCDW at C11. In contrast to the similarity of the $\mathrm{dFe}$ profiles, the $\mathrm{pFe}$ profile at $\mathrm{C} 11$ was generally lower than at R-2, with mean values through the water column of $0.2 \pm 0.14 \mathrm{nmol} \mathrm{L}^{-1}$ (Andrew Bowie, unpublished data) compared to $0.53 \pm 0.35 \mathrm{nmol} \mathrm{L}^{-1}$ for station R-2.

\subsubsection{Plateau station A3}

Stations A3-1 (Fig. 3b) and A3-2 (Fig. 3c) were in relatively shallow waters on the central plateau, and were impacted by plateau sediments and possibly fluvial and glacial runoff from the basaltic rocks of Heard Island $\sim 300 \mathrm{~km}$ upstream (van der Merwe et al., 2015; M. Grenier, personal communication, 2014). A pycnocline was observed at $\sim 190 \mathrm{~m}$, above which the salinity (33.9) and nitrate $\left(\sim 29 \mu \mathrm{mol} \mathrm{L}^{-1}\right)$ were relatively constant. The mixed layer shoaled (from 165 to $123 \mathrm{~m}$ ) and increased in temperature (from 1.7 to $2.2^{\circ} \mathrm{C}$ ) between the two visits to $\mathrm{A} 3$, consistent with springtime warming of surface waters. We believe that the water masses at A3-1 and A3-2 are comparable since surface waters move slowly in this region (Park et al., 2008, 2014a; Zhou et al., 2014); this was confirmed by REE data which indicated similar waters at both stations marked with fresh continental supplies and only modified by biological processes (M. Grenier, personal communication, 2014).

Surface chlorophyll images revealed that during the 28 days between the first and second visits to A3, a large diatom spring bloom developed mostly dominated by lightly silicified Chaetoceros spp. (surface $\mathrm{Chl} a$ increasing from $0.2 \mu \mathrm{g} \mathrm{L}^{-1}$ at A3-1 to $1.3 \mu \mathrm{g} \mathrm{L}^{-1}$ at A3-2; Lasbleiz et al., 2014), which likely resulted in the drawdown of $\mathrm{dFe}$ (mean mixed layer values decreasing from $0.3-0.4 \mathrm{nmol} \mathrm{L}^{-1}$ at A31 to $0.1-0.2 \mathrm{nmol} \mathrm{L}^{-1}$ at A3-2). The peak of biomass had passed by the time we sampled at A3-2, with the bloom starting to fade (Trull et al., 2015). Below the mixed layer, similar $\mathrm{dFe}$ profiles were observed during both visits to $\mathrm{A} 3$, with expected significant increases at depth towards the plateau floor (e.g. to $1.30 \mathrm{nmol} \mathrm{L}^{-1}$ at $480 \mathrm{~m}$ at A3-2; note that, due to operational constraints, there was no $\mathrm{dFe}$ data deeper than $340 \mathrm{~m}$ at A3-1). Such enrichments at depth were also observed in dissolved Mn and Co profiles (F. Quéroué, personal communication, 2014; data not shown) and dFe profiles from the occupations of station A3 during KEOPS-1 (Fig. 4b), indicative of plateau sedimentary supply.

The $\mathrm{pFe}$ profiles at $\mathrm{A} 3$ showed a similar structure to the $\mathrm{dFe}$ profile, with lower values at the surface $\left(<10 \mathrm{nmol} \mathrm{L}^{-1}\right.$ at A3-1 and $<4 \mathrm{nmol} \mathrm{L}^{-1}$ at A3-2) and increasing with depth 

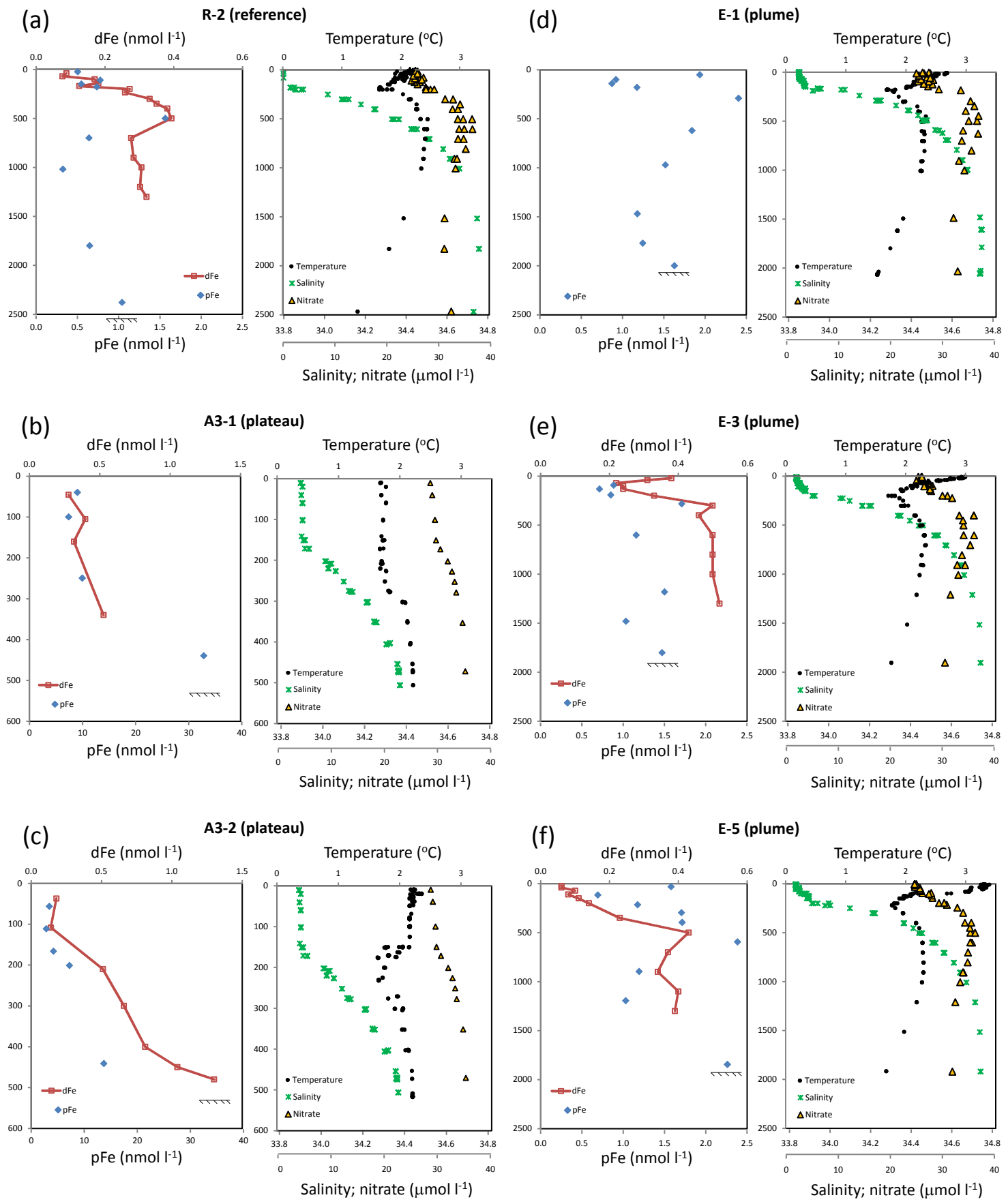

Figure 3. (a) Vertical profiles of dissolved iron $(\mathrm{dFe})$ and particulate iron $(\mathrm{pFe})$, potential temperature, salinity, and nitrate at reference station R-2. The seafloor depth at $2528 \mathrm{~m}$ is shown. (b, c) Vertical profiles of dFe and pFe, potential temperature, salinity, and nitrate at plateau stations A3-1 (b) and A3-2 (c). The seafloor depth at 530 m is shown. Note different scales for dFe and pFe compared to R-2 and E stations. (d, e, f) Vertical profiles of $\mathrm{dFe}$ and pFe, potential temperature, salinity, and nitrate at plume stations E1 (d), E3 (e) and E5 (f). The seafloor depth ranging from $1905 \mathrm{~m}$ (E3) to $2057 \mathrm{~m}$ (E1) is shown.

due to enrichment from bottom sediments (up to 33 and $14 \mathrm{nmol} \mathrm{L}^{-1}$ at $440 \mathrm{~m}$ at A3-1 and A3-2, respectively), and were on average 10 times greater than dissolved concentrations through the water column. The mixed layer $\mathrm{pFe}$ con- centrations changed remarkably between the two visits, and the full water column integrated pool was $\sim 70 \%$ lower at A3-2 than at A3-1. Interestingly, this change was also associated with a shift of particles from the $1-53 \mu \mathrm{m}$ size range 


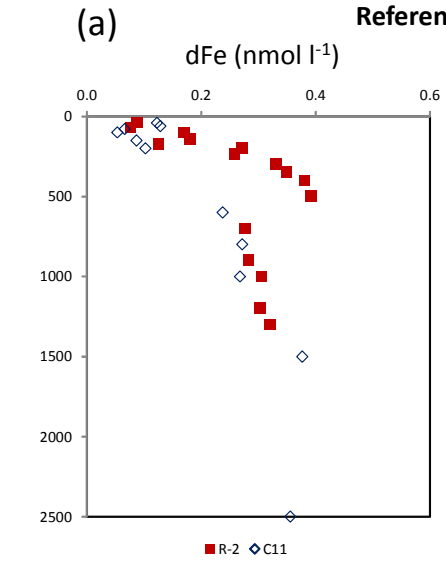

Reference stations

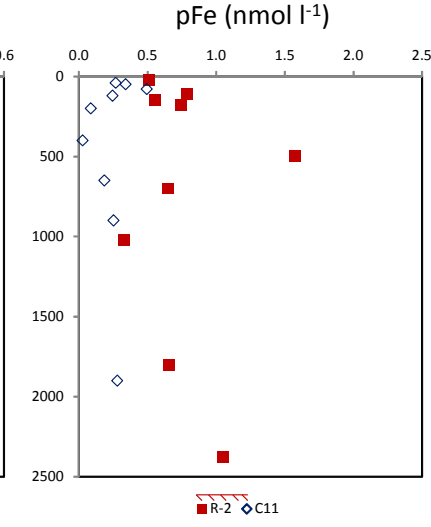

(b)
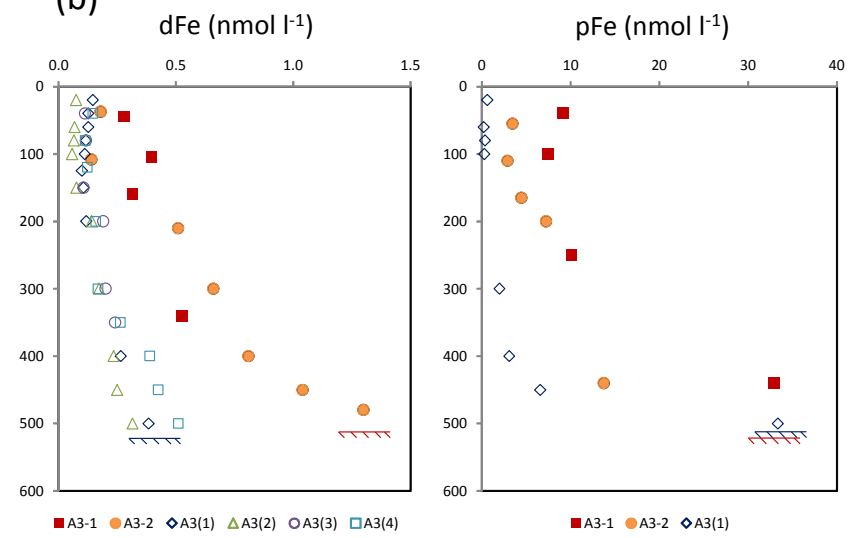

Figure 4. (a) Comparison of $\mathrm{dFe}$ and $\mathrm{pFe}$ at reference stations for KEOPS-1 (station C11, open blue diamonds) and KEOPS-2 (station R-2, closed red squares). The water depths were $3110 \mathrm{~m}$ at $\mathrm{C} 11$ and $2530 \mathrm{~m}$ at R-2. (b) Comparison of $\mathrm{dFe}$ and $\mathrm{pFe}$ at $\mathrm{A} 3$ plateau stations for KEOPS-1 (open symbols) and KEOPS-2 (closed symbols). Data are shown for all visits to A3 on both KEOPS cruises. Note difference in scale for $\mathrm{dFe}$ and $\mathrm{pFe}$ between (a) and (b).

to the $>53 \mu \mathrm{m}$ size range, with the larger class tripling in size (van der Merwe et al., 2015). The development of the large bloom between our two visits to A3, which consisted of a diatom community 50-210 $\mu \mathrm{m}$ in size (Trull et al., 2015), was likely responsible for converting the $\mathrm{pFe}$ within the surface mixed layer from the smaller size class to the larger size class. This may have been due to either (i) physical aggregation of the particles onto diatom aggregates and/or (ii) microbially driven conversion of small lithogenic $\mathrm{Fe}(1-53 \mu \mathrm{m})$ to bioavailable forms and incorporation into the large $(>53 \mu \mathrm{m})$ diatoms as biogenic $\mathrm{Fe}$, with potentially some fraction of these larger particles exported to depths below the mixed layer, as previously discussed by Lam et al. (2006), Frew et al. (2006) and Planquette et al. (2011).

The spring (Oct-Nov) KEOPS-2 Fe profiles at station A3 showed a similar structure to those from the late summer (Jan-Feb) during KEOPS-1, with surface depletion, concen- trations increasing with depth and enrichment just above the plateau seafloor (Fig. 4b). Through the water column, dFe was between 2 and 5 times greater during KEOPS-2 than KEOPS- 1 and $\mathrm{pFe}$ was $\sim 10$ times greater during KEOPS-2 (with the exception of the deepest samples). The lower values during KEOPS-1 were likely the result of biological uptake in surface waters and the export of $\mathrm{Fe}$ during the spring bloom prior to our arrival at the study site, combined with seasonal changes in the strength of the supply mechanisms to deeper waters at A3 (discussed in van der Merwe et al., 2015).

\subsubsection{Plume E stations}

The E stations within the bathymetrically trapped complex recirculation system showed similar hydrographic and nutrient distributions below the mixed layer (Fig. 3d, e and f), which shoaled from $64 \mathrm{~m}$ at E-1 to $32 \mathrm{~m}$ at E-3 to $39 \mathrm{~m}$ at $\mathrm{E}-5$, with some internal variability in water column structure at mid-depths. Surface waters warmed from 2.7 to $3.4{ }^{\circ} \mathrm{C}$ between the occupations of E-1 and E-5, although no significant nitrate drawdown was observed (Blain et al., 2015). Below AASW, a subsurface temperature minimum $\left(T_{\min }, \sim 1.7^{\circ} \mathrm{C}\right)$ was observed between $180 \mathrm{~m}$ (E1) and $220 \mathrm{~m}$ (E5), characteristic of WW. The $T_{\min }$ feature is associated with waters south of the PF, although the recirculation feature probably also received SAZ waters mixed in from the north (d'Ovidio et al., 2015). $T, S$ and $\mathrm{O}_{2}$ characteristics indicated the presence of UCDW $(\sim 600-700 \mathrm{~m})$ and LCDW (deeper than $\sim 1300 \mathrm{~m}$ ) deeper in the water column above the seafloor (Quéroué et al., 2015). Water parcel trajectories calculated from altimetry based geostrophic currents indicated that it took generally $>2$ months for Fe-rich waters from the plateau to travel to the downstream plume site associated with the recirculation feature (E stations) (d'Ovidio et al., 2015). However shorter transport times are also possible due to episodic transport across the PF (Sanial et al., 2015).

Waters at the plume stations showed the largest spatial heterogeneity in surface biomass as revealed by the evolution of a mosaic of complex blooms seen in satellite images (see Supplement in Trull et al., 2015). We observed moderate surface Chl $a$ levels ranging from $0.3-0.4 \mu \mathrm{g} \mathrm{L}^{-1}$ at E-1 and E-3 to $0.5-0.9 \mu \mathrm{g} \mathrm{L}^{-1}$ at E-5 (Lasbleiz et al., 2014), noting that as much as $50 \%$ of the chlorophyll was below the mixed layer at the plume stations due to stratification of the upper water column in the warm, spring conditions. Unlike the plateau bloom dominated by large cells $>53 \mu \mathrm{m}$, the community in the plume E stations was more mixed (LaurenceauCornec et al., 2015), with cells present in both the 5-20 and 50-200 $\mu \mathrm{m}$ size classes (Trull et al., 2015). The E stations showed the highest $\mathrm{C}$ export fluxes of all regions as estimated from Th deficits, nitrate depletions and free-drifting sediment trap observations (Planchon et al., 2015; Trull et al., 2015; Laurenceau-Cornec et al., 2015). 
Due to operational constraints, no $\mathrm{dFe}$ data were available at station E-1. The $\mathrm{dFe}$ vertical profiles at E-3 and E-5 were quite different, with a distinct surface enrichment to $0.4 \mathrm{nmol} \mathrm{L}^{-1}$ at E-3 above a minimum of $0.2 \mathrm{nmol} \mathrm{L}^{-1}$ at $100 \mathrm{~m}$. This feature was absent at station E-5, where $\mathrm{dFe}$ was depleted to $<0.1 \mathrm{nmol} \mathrm{L}^{-1}$ at the surface, likely due to biological $\mathrm{Fe}$ uptake, which was highest at E-5 $\left(1745 \mathrm{nmol} \mathrm{m}^{-2} \mathrm{~d}^{-1}\right)$ compared to A3-2 $\left(1120 \mathrm{nmol} \mathrm{m}^{-2} \mathrm{~d}^{-1}\right)$ (Table 1) and E-4E (880 nmol m${ }^{-2} \mathrm{~d}^{-1}$; data not shown), despite lower POC and primary production (see discussion below and Fourquez et al., 2015). Deeper in the water column $(>500 \mathrm{~m})$ at E stations, $\mathrm{dFe}$ was broadly uniform $\left(0.3-0.5 \mathrm{nmol} \mathrm{L}^{-1}\right)$.

The $\mathrm{pFe}$ distributions at the three $\mathrm{E}$ stations were similar with a surface $(35-40 \mathrm{~m})$ enrichment $\left(1.6-1.9 \mathrm{nmol} \mathrm{L}^{-1}\right)$, a minimum at $\sim 100-200 \mathrm{~m}$ below the mixed layer $(0.7-$ $0.9 \mathrm{nmol} \mathrm{L}^{-1}$; broadly consistent with the $T_{\min }$ layer), a maximum at $280-600 \mathrm{~m}\left(1.7-2.4 \mathrm{nmol} \mathrm{L}^{-1}\right)$, and with evidence of enrichment near the seafloor at depths $>1800 \mathrm{~m}$ (up to $1.5-2.3 \mathrm{nmol} \mathrm{L}^{-1}$ ). By applying biogenic (using P) and lithogenic (using $\mathrm{Al}$ ) normalisers to the data (see Sect. 3.2 below), surface $\mathrm{pFe}$ enrichment was roughly equally composed of biogenic and lithogenic Fe, whilst the 300-600 m maximum was predominantly composed of lithogenic $\mathrm{Fe}$ (>100-fold greater than biogenic Fe at these depths). This lithogenic Fe was most likely from waters enriched by sediments and transported laterally eastward off the Kerguelen Plateau which sits at $\sim 530 \mathrm{~m}$ below the sea surface. There was no obvious change in $\mathrm{pFe}$ in surface or deep waters during the bloom evolution at the pseudo-Lagrangian E stations.

KEOPS -1 only occupied one station in the plume east of the Kerguelen Islands (A11 at $49^{\circ} 09^{\prime} \mathrm{S} 74^{\circ} 00^{\prime} \mathrm{E}$ ). Dissolved $\mathrm{Fe}$ at $\mathrm{A} 11$ ranged from $0.09 \mathrm{nmol} \mathrm{L}^{-1}$ at the surface to $0.17 \mathrm{nmol} \mathrm{L}^{-1}$ at $1500 \mathrm{~m}$ (Blain et al., 2008b), and $\mathrm{pFe}$ ranged from $0.07 \mathrm{nmol} \mathrm{L}^{-1}$ at the surface to $0.81 \mathrm{nmol} \mathrm{L}^{-1}$ at $1500 \mathrm{~m}$ (Andrew Bowie, unpublished data); thus, it was much lower than our KEOPS-2 observations at the E site (noting that different sampling and digestion methods for $\mathrm{pFe}$ were used for the two cruises).

\subsection{Construction of iron budgets}

The primary aim of this work was to use our observations of $\mathrm{Fe}$ pools and fluxes to understand the sources, sinks and biological Fe cycling and to evaluate whether Fe supply could meet demand in both the high-Fe and low-Fe environments in the vicinity of the Kerguelen Archipelago during KEOPS2. Iron budgets have been constructed for previous studies in waters fertilised with Fe both naturally (Sarthou et al., 2008; Bowie et al., 2009; Chever et al., 2010; Ellwood et al., 2014) and artificially (Bowie et al., 2001) as well as low-Fe conditions (Price and Morel, 1998; Boyd et al., 2005). These budgets have combined geochemical and chemical components to demonstrate that the dominant long-term fluxes of $\mathrm{Fe}$ are associated with the particulate pool (dust supply and particle export), whilst studies on Fe uptake and microbial cycling have shown that short-term fluxes within the "ferrous wheel" are dominated by biological uptake and remineralisation (Strzepek et al., 2005). Here, we follow a similar approach to that used by Bowie et al. (2009) for the SAZSense study south of Tasmania (Australia) at our three study sites. Since all parameters in our iron budget calculations were only measured at stations R-2, A3-2 and E-5, discussion will focus on these stations. Data for stations A3-1, E-1 and E-3 are given to provide a context for spatial and temporal changes in the Fe pools and fluxes during KEOPS-2, and they are collated in Table 1.

\subsubsection{Iron pools}

Iron and carbon pools were calculated by integrating the dissolved and particulate profiles down to the base of the surface mixed layer, defined as the depth where the potential density equalled the potential density at $10 \mathrm{~m}+0.02 \mathrm{~kg} \mathrm{~m}^{-3}$ (Park et al., 2014a). The mixed layer varied from $165 \mathrm{~m}$ at station A31 to $32 \mathrm{~m}$ at station E-3, consistent with the seasonal shoaling as surface waters warmed, but it remained deep $(>120 \mathrm{~m})$ on the plateau throughout the study due to deep mixing as a result of several passing storms.

Integrated pools of both dissolved $(\sim 5 \times)$ and particulate $(\sim 10 \times)$ Fe were significantly greater on the plateau (station A3) compared to in the plume (station E), with stocks at the reference station R-2 lower still. Horizontal dFe supply from the plateau to the plume was either or both via (i) a geostrophic path looping along the northern side of the PF and then back into the recirculation feature (d'Ovidio et al., 2015) and (ii) direct Ekman flux transport of Fe-rich coastal water across the PF driven by westerly winds, as indicated by Ra tracers (Sanial et al., 2015). The latter process is supported by Lagrangian trajectories of water parcels derived from altimetry, which showed the PF was not a strong barrier to water mass movement, with transport of waters across the front taking place on timescales of days to weeks but being highly variable in space and time (d'Ovidio et al., 2015). The pFe pool showed the same variability as the dissolved pool at our three study sites and exceeded the dFe stocks at all sites by factors of approximately 19-26 (A3), 31 (E) and 6 (R-2), although it is estimated that only $\sim 2-3 \%$ of the particulate pool can be converted into bioavailable forms by physically or biologically mediated dissolution (Schroth et al., 2009). If we assume that station A3-1 represented pre-bloom conditions and the integrated mixed layer pool of $54 \mu \mathrm{mol} \mathrm{dFe} \mathrm{m}^{-2}$ was a good estimate of the winter stock, observations show that only 4 weeks later at station A3-2, almost $60 \%$ of the winter stock had been drawn down to $21 \mu \mathrm{mol} \mathrm{m}^{-2}$. If annual variability is low, which may not always be the case (Grenier et al., 2015), by late summer $>90 \%$ of the winter stock had been used with only $4.7 \mu \mathrm{mol} \mathrm{dFe} \mathrm{m}^{-2}$ remaining in the surface mixed layer at A3 (KEOPS-1 data; Blain et al., 2007). We note that this drawdown is probably a con- 
Table 1. Summary of iron standing stocks and fluxes for the upper mixed layer at KEOPS-2 process station sites R-2 (reference), A3 (plateau) and E (plume). For full details of the calculations, see text. Error bounds are provided where available. Due to logistical constraints resulting in missing data at some stations, we will focus on R-2, A3-2 and E-5 in the discussion. Data for stations A3-1, E-1 and E-3 are given to provide a context for spatial and temporal changes in the pools and fluxes during KEOPS-2.

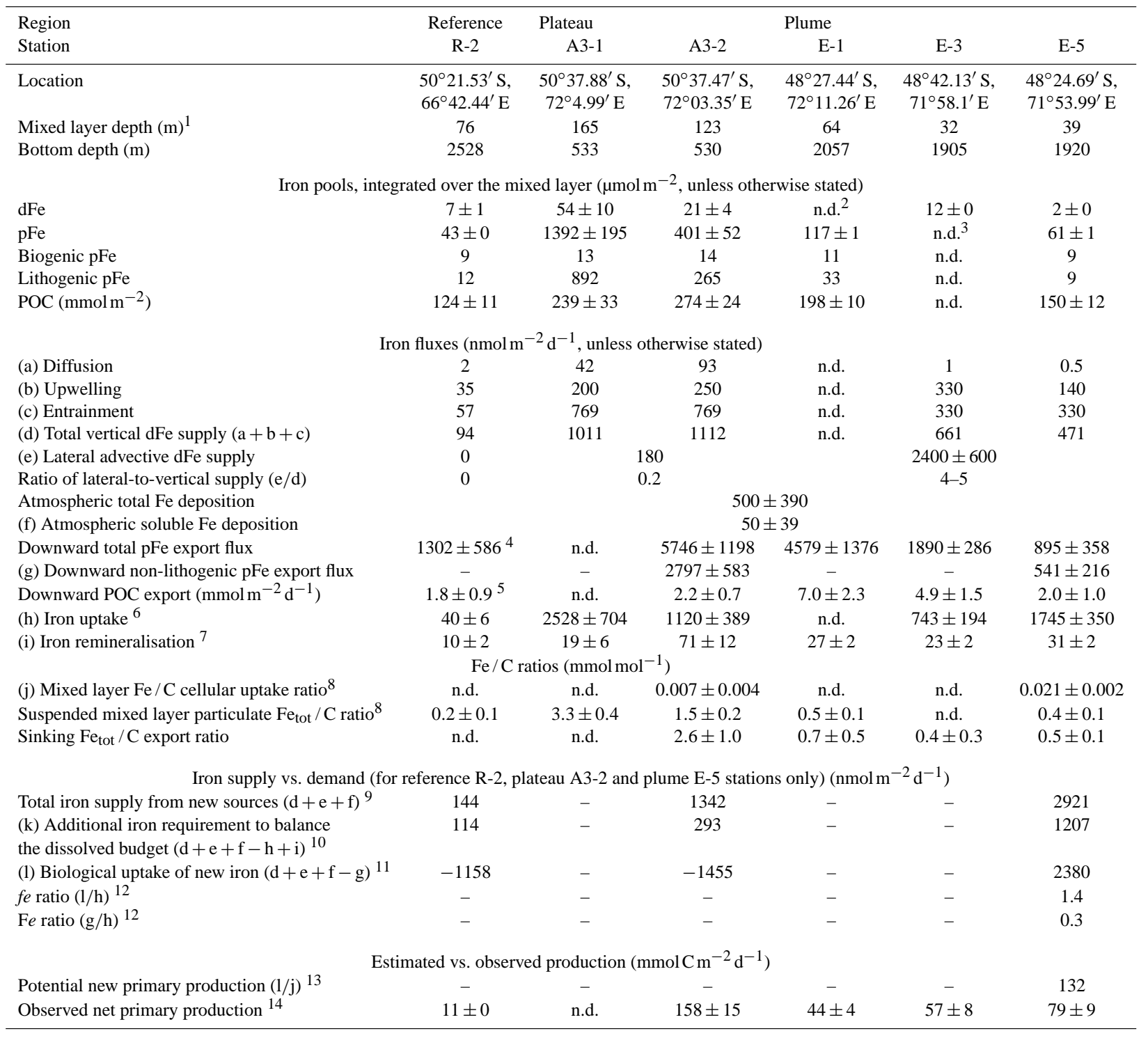

n.d.: no data
1 The mixed layer depths were calculated on the density plane to allow for heave (internal tides driven by topography) and other localised events.

2 Due to logistical reasons there was no TMR cast for dFe at station E-1.

3 Due to ISP failure, there were no mixed layer samples for pFe at station E-3.

${ }^{4}$ The P-trap was lost at R-2. We therefore estimated the pFe export flux using the ${ }^{234}$ Th flux in suspended particles at $200 \mathrm{~m}^{(449} \pm 203 \mathrm{dpm} \mathrm{m}^{-2} \mathrm{~d}^{-1}$; from Table 1 in Planchon et al., 2014$)$ and a mean $\mathrm{Fe} / \mathrm{Th}$ ratio collected in the upper $200 \mathrm{~m}$ above the trap $\left(2.9 \pm 1.3 \mathrm{nmol} \mathrm{dpm}^{-1}\right)$

${ }_{6}^{5}$ Estimated using the ${ }^{234} \mathrm{Th}$ flux and $\mathrm{Fe} / \mathrm{C}$ ratio in suspended particles at $200 \mathrm{~m}$.

${ }^{6}$ For stations R-2, A3-1, E-1 and E-3, seawater for iron uptake experiments were conducted for small cells filtered through a $25 \mu \mathrm{m}$ mesh. This size fraction represented between 77 and $91 \%$ of the total POC pool. At stations A3-2 and E-5, we also used unfiltered seawater for our uptake experiments. Similar results were obtained for both the 0.2-25 $\mu$ m and unfiltered fractions at station A3-2. ${ }^{7}$ Includes bacterial and mesozooplankton contributions.

${ }^{8}$ Mean of all samples collected in the mixed layer.

${ }^{9}$ Assumes that only the soluble iron atmospheric supply is available (see text)

${ }^{10}$ A negative value indicates an additional iron requirement.

11 At stations R-2 and A3-2, the negative values most likely occurred due to differences in the timescales of observations and calculations of fluxes (parameters were decoupled in time). The iron budget was based on an instantaneous picture of different fluxes that were not strictly measured at the same time (i.e. export fluxes operated on a different time frame to the iron supply (vertical, lateral and atmospheric) and were very large at R-2 and A3-2).

$12 f e$ : uptake of new / (uptake of new + regenerated iron $F_{\mathrm{e}}$ ): biogenic iron export / (uptake of new + regenerated iron) (Boyd et al., 2005). Note the $f e$ and $F_{\mathrm{e}}$ ratios have considerable plasticity due to uncertainties in the lithogenic vs. biogenic fraction of exported particulate iron and the missing iron source at A3-2.

13 Calculated using the biological uptake of new iron (k) and molar Fe/ C cellular uptake ratio (j).

${ }^{14}$ Net primary production (NPP) integrated within the euphotic zone down to $1 \%$ PAR, based on ${ }^{13} \mathrm{C}$ incorporation (Cavagna et al., 2014). 
servative estimate since the winter $\mathrm{dFe}$ stock was probably an underestimation (as evidenced by lower $\mathrm{dFe}$ in the mixed layer compared to deep waters at A3-1; Quéroué et al., 2015). Biogenic iron (defined as the $\mathrm{Fe}$ associated with living phytoplankton and phytoplankton biodetritus) was calculated by assuming that all particulate phosphorus $(\mathrm{P})$ was of biogenic origin and multiplying the mean particulate $\mathrm{P}$ concentration in the mixed layer at each station by a maximum intracellular $\mathrm{Fe} / \mathrm{P}$ ratio of $1.9 \mathrm{mmol} \mathrm{mol}^{-1}$ for natural phytoplankton assemblages measured by Twining et al. (2004) for Fe-replete conditions. These calculations follow methods reported in Planquette et al. (2013) and assume that particulate $\mathrm{P}$ is not (in part) derived from local rock weathering. Van der Merwe et al. (2015) have tested this assumption using $\mathrm{Fe} / \mathrm{P}$ ratios in the Kerguelen Islands basalts and the upper continental crust and note that the $\sim 1000$-fold increase in $\mathrm{pP}$ within suspended particles can only be explained by $\mathrm{pP}$ produced in situ within the mixed layer from dissolved $\mathrm{PO}_{4}^{-}$. Lithogenic Fe was calculated by assuming that all particulate aluminium ( $\mathrm{pAl}$ ) was of lithogenic origin and by multiplying the mean pAl concentration in the mixed layer by a lithogenic $\mathrm{Fe} / \mathrm{Al}$ ratio of $0.36 \mathrm{~mol} \mathrm{~mol}^{-1}$, which is the mean value based on basaltic rocks from the Crozet region (0.51; Gunn et al., 1970) and crustal materials (0.2; Wedepohl, 1995). The selected $\mathrm{Fe} / \mathrm{Al}$ ratio of $0.36 \mathrm{~mol} \mathrm{~mol}^{-1}$ is also very similar to that of 0.33 used extensively in earlier calculations (Taylor and McLennan, 1989) and reported for the deep Atlantic Ocean (Sherrell and Boyle, 1992). This approach is dependent not only on the chosen $\mathrm{Fe} / \mathrm{Al}$ ratio but also assumes that processes other than biological assimilation, such as adsorption and scavenging onto organic particles, photoreduction, surface precipitation, and chemically and biologically driven dissolution, are not significant (Measures et al., 2008; Planquette et al., 2011, 2013; Ellwood et al., 2014). Since biogenic and lithogenic Fe were calculated independently, their sum may be less than the observed total particulate Fe concentration. This is likely due to plasticity in the chosen $\mathrm{Fe} / \mathrm{Al}$ and $\mathrm{Fe} / \mathrm{P}$ ratios and differential remineralisation rates for $\mathrm{Fe}, \mathrm{Al}$ and $\mathrm{P}$. Nevertheless, our estimates of biogenic and lithogenic Fe provide a perspective on the relative contributions to the total $\mathrm{pFe}$ pool.

Reference and plume waters contained roughly an equal fraction of biogenic and lithogenic $\mathrm{Fe}$. The origin of this biogenic $\mathrm{Fe}$ pool will be a combination of biological uptake of $\mathrm{dFe}$, physical adsorption onto suspended biological particles, and conversion from the lithogenic fraction (likely driven by microbes), with these processes operating on different timescales (Boyd et al., 2005; Frew et al., 2006; Planquette et al., 2011). By contrast, the plateau stations contain 19-69 times more lithogenic Fe than biogenic Fe, consistent with the supply from the nearby sediments of the plateau and Heard Island, as suspected by Zhang et al. (2008), van Beek et al. (2008) and discussed in Chever et al. (2010). The measurement of other geochemical "fingerprint" particulate tracers (such as $\mathrm{Al}, \mathrm{Mn}$ ) on the plateau confirmed the provenance of Fe supplied from the Kerguelen shelf sediments in the particulate phase (van der Merwe et al., 2015).

\subsubsection{Internal iron supply}

Vertical fluxes were calculated as follows. A vertical diffusivity $\left(K_{\mathrm{z}}\right)$ at the base of mixed layer of $10^{-5} \mathrm{~m}^{2} \mathrm{~s}^{-1}$ was used for the plume and reference site, and a $K_{\mathrm{Z}}$ of $3 \times 10^{-4} \mathrm{~m}^{2} \mathrm{~s}^{-1}$ was used for the plateau site, estimated from the Shih parameterisations (Shih et al., 2005) using the Thorpe scale method (Park et al., 2014b). These values are comparable to $K_{\mathrm{z}}$ values estimated for KEOPS 1 using the Osborn model $\left(4 \times 10^{-4} \mathrm{~m}^{2} \mathrm{~s}^{-1}\right.$; Osborn, 1980) (Park et al., 2008a). Vertical diffusivity was multiplied by the vertical $\mathrm{dFe}$ gradient for each profile, which was determined using the linear part of the vertical profiles corresponding to the $150-200 \mathrm{~m}$ depth strata in Fig. 3a-f, consistent with calculations for KEOPS-1 (Blain et al., 2007). Vertical diffusivity of Fe was negligible at reference and plume sites but significant on the plateau due to both the higher vertical diffusivity and the steeper $\mathrm{Fe}$ gradient between 150 and $200 \mathrm{~m}$.

Upwelling was defined as the vertical velocity $\left(w_{\mathrm{ek}}\right)$ multiplied by the $\mathrm{dFe}$ concentration at $200 \mathrm{~m}$, which corresponds to the depth of the remnant winter water. The magnitude of vertical velocity in this region has recently been studied by Rosso et al. (2014), who used the MIT general circulation model to examine the sensitivity of the vertical velocity to the horizontal resolution. They found clear differences in $w_{\mathrm{ek}}$ due to the development of near-surface sub-mesoscale frontal structures that only their highest-resolution model was able to resolve. Rosso et al. (2014) reported vertical velocities for individual water parcels in excess of $100 \mathrm{~m} \mathrm{day}^{-1}$ in the Kerguelen region, with $w_{\text {ek }}$ stronger in the downstream plume. Both the horizontal and vertical circulations were much weaker over the plateau since it acts as a natural barrier to the strong ACC fronts coming from the west. Unfortunately, no seasonal cycle was included in the model forcing. Therefore the temporal root mean square of the vertical velocity reported in Fig. 12b of Rosso et al. (2014) was used for the plateau and plume sites $\left(w_{\mathrm{ek}}=0.5\right.$ and $1 \mathrm{~m} \mathrm{~d}^{-1}$, respectively), and a conservative value of $w_{\mathrm{ek}}=0.13 \mathrm{~m} \mathrm{~d}^{-1}$ for the open Southern Ocean (used by de Baar et al., 1995; originally reported in Gordon et al., 1977) was chosen for our reference station. Although $w_{\text {ek }}$ was lower on the plateau compared to the plume, the higher $\mathrm{dFe}$ concentration at $200 \mathrm{~m}$ resulted in comparable estimates of upwelled Fe (Table 1).

Entrainment of $\mathrm{Fe}$ by episodic (intraseasonal) deepening of the mixed layer has rarely been taken into account in field studies (Frants et al., 2013) due to the absence of data characterising the short-term variability of the mixed layer depth, yet a recent compilation of observations (Nishioka et al., 2011; Tagliabue et al., 2014) and modelling studies (Mongin et al., 2008) suggests that entrainment could be a major vertical supply mechanism fuelling surface biomass (Carranza et al., 2015). We used more than 6000 vertical profiles of 
salinity and temperature collected in the KEOPS-2 regions of interest to estimate the seasonality of the mixed layer depth and its variability (Supplement Fig. 3). We derived the vertical supply of Fe by entrainment via hypotheses regarding the relation between the size of mixed layer depth excursions and their frequency (see the Supplement). Entrainment data based on transient deepening of the mixed layer was not available for station R-2; therefore we calculated this by multiplying the $\mathrm{dFe}$ concentration in winter water (which reflects the dFe concentration of the winter mixed layer) by the winter mixed layer depth (MLD) and assume that this entrainment event happens once per year. "Detrainment" at R-2 was accounted for by multiplying this new entrainment flux by the summer-to-winter MLD ratio.

For the vertical fluxes, in spring on KEOPS-2, entrainment was the dominant vertical Fe flux term on the plateau, delivering $\sim 70 \%$ of the total vertical supply and tripling the total vertical flux in comparison to budgets that neglect this process. At the plume and reference sites, entrainment was comparable to the upwelling flux. Vertical diffusion accounted for $4-8 \%$ of the total vertical supply on the plateau. In contrast, the contribution from $\mathrm{dFe}$ entrainment was much reduced in late summer on KEOPS-1 (42 and $8.8 \mathrm{nmol} \mathrm{m}^{-2} \mathrm{~d}^{-1}$ for plateau and plume, respectively) due to the deepening and weakening of the ferricline (Fig. 4b). The relative magnitude of the total vertical Fe supply terms at the three study sites was plateau $>$ plume $>$ reference (Table 1 , row d).

For the lateral fluxes, the horizontal supply at reference station R-2 was assumed to be zero since HNLC waters upstream and downstream of this station contained similar $\mathrm{dFe}$ and $\mathrm{pFe}$ concentrations, and as phytoplankton growth and biomass was low at this site, there would be little biogenic Fe exported below the mixed layer. On the plateau, Fe supply at station A3 was taken from the steady-state box model of Chever et al. (2010), which used the horizontal dFe gradient and current velocities from Park et al. (2008a) to calculate the lateral flux of $180 \mathrm{nmol} \mathrm{m}^{-2} \mathrm{~d}^{-1}$ in the $0-150 \mathrm{~m}$ depth band above the plateau; note that this model used KEOPS-1 data. Lateral transport into the plume E stations was assumed to originate from Fe-fertilised plateau waters that were advected offshore (d'Ovidio et al., 2015). This value was estimated by assuming that horizontal stirring occurs in a Lagrangian framework and using altimetry-derived geostrophic velocities to determine transport across the plateau boundary. We also used a depth band of 0-150 m, considered as the winter mixed layer in the plume over the season. These estimates were combined with direct measurements of the $\mathrm{dFe}$ content of three different types of on-plateau stations to calculate the lateral flux over a 3-month supply period prior to the spring bloom, namely (i) two coastal stations near the Kerguelen Islands occupied on KEOPS-2 (stations TEW-1 and TEW-2), (ii) one coastal station close to Heard Island occupied during KEOPS-1 (station C1) and (iii) the central plateau station A3 considered here. This resulted in $5.4 \times 10^{7} \mathrm{~mol}$ Fe per day being injected into a plume size (defined at a threshold of $>0.3 \mu \mathrm{g}$ Chl $a \mathrm{~L}^{-1}$ and identified from satellite images) of $2.5 \times 10^{11} \mathrm{~m}^{2}$ over 90 days in spring (full details of the calculations are contained in d'Ovidio et al., 2015). This equated to a lateral flux into the plume of $2400 \mathrm{nmol} \mathrm{m}^{-2} \mathrm{~d}^{-1}$ in the October-November period.

By combining our in situ Fe measurements with estimated ages of the water bodies in the plume, we calculate a first-order exponential scavenging removal constant between 0.041 and $0.058 \mathrm{~d}^{-1}$, which equated to a residence time of 17 to 24 days, consistent with estimates based on the $\mathrm{Fe}$ inventory and Fe export in free-floating traps (15-79 days; Laurenceau-Cornec et al., 2015). Since the total of the vertical and lateral fluxes in the plume were more than double those on the plateau, this may imply that the source waters supplying the plume from the northern Kerguelen Islands shelves (which had a uniquely narrow $T-S$ class in surface waters; Grenier et al., 2015) were richer in Fe than the plateau further south at A3. This is supported by observations of $\mathrm{dFe}$ in the surface ocean at stations TEW-1 and TEW-2 (1.2$1.8 \mathrm{nmol} \mathrm{L}^{-1}$ ), which were close to Hillsborough Bay in waters only 86 m deep (Quéroué et al., 2015).

Considering only internal processes (diffusion, upwelling, entrainment, lateral transport) in supplying Fe to the surface mixed layer, the vertical terms dominated at the reference station; vertical terms were 6-fold greater than lateral terms on the plateau, whereas lateral advection was the dominant term in the plume (4-5-fold greater than the vertical terms). Since the particulate Fe stocks were abundant in surface waters (above the winter temperature minimum layer) and significantly higher than the dissolved pools (most notably on the plateau), it is likely that a fraction of the suspended lithogenic pFe from Heard Island or the Kerguelen Plateau sediments also contributed to the internal dFe supply and fuelled biological responses. This is discussed in more detail later.

\subsubsection{External iron supply}

Data on atmospheric Fe fluxes through dust deposition and the solubility of $\mathrm{Fe}$ in the dust for all three study sites were taken from the nearby land-based sampling site "Jacky" (49 $18^{\prime} 42.3^{\prime \prime} \mathrm{S}, 70^{\circ} 07^{\prime} 47.6^{\prime \prime} \mathrm{E}$; altitude $250 \mathrm{~m}$ ) on the Kerguelen Islands, as reported in Heimburger et al. (2012, 2013a). Mean total Fe fluxes taken over the period 24 November 2008 to 07 September 2010 were $500 \pm 390 \mathrm{nmol} \mathrm{m}^{-2} \mathrm{~d}^{-1}$ (Heimburger et al., 2013a), which was comparable to the Crozet region upstream $\left(895 \mathrm{nmol} \mathrm{m}^{-2} \mathrm{~d}^{-1}\right.$; Planquette et al., 2007) and the Southern Ocean sector south of Australia (288-488 $\mathrm{nmol} \mathrm{m}^{-2} \mathrm{~d}^{-1}$; Bowie et al., 2009) but greater than the flux value estimated by Wagener et al. (2008) during KEOPS-1 (14$46 \mathrm{nmol} \mathrm{m}^{-2} \mathrm{~d}^{-1}$ ). The remoteness of the Kerguelen region means it receives low quantities of atmospheric material (Heimburger et al., 2012; Wagener et al., 2008), the majority of which is crustal in origin, such as desert dust from South America, South Africa or Australia (Prospero et al., 2002; 
Mahowald, 2007; Bhattachan et al., 2012), although local anthropogenic activities, rock outcrops and exposed soil may also impact dust fluxes.

Atmospheric fluxes were dominated by wet deposition (Heimburger et al., 2012). Heimburger et al. (2013b) calculated the mean "soluble" Fe deposition flux (defined as $<0.2 \mu \mathrm{m}$ ) using a median solubility of $82 \pm 18 \%$ in rainwater on the Kerguelen Islands. These high solubilities were attributed to the remoteness of the sampling location from dust sources resulting in strong cloud chemical processing during transport. However, the solubility of Fe dissolved in seawater at higher pH will be much lower (Schroth et al., 2009; Sedwick et al., 2007). Hence a conservative value of $10 \%$ of $\mathrm{Fe}$ that is released into seawater was chosen (Baker et al., 2006; Mackie et al., 2006) for our budgets here, resulting in a soluble $\mathrm{Fe}$ atmospheric deposition flux to the Kerguelen region of $50 \mathrm{nmol} \mathrm{m}^{-2} \mathrm{~d}^{-1}$ (Table 1, row $\mathrm{f}$ ). This value was lower than the internal vertical supply on the plateau $(\sim 20$-fold $)$ and plume ( $\sim 10$-fold), insignificant compared to the lateral supply to the plume but comparable to the lateral supply on the plateau. Although volcanic ash has not been considered here for atmospheric Fe supply, this term may have played an important role for primary productivity on the Kerguelen Plateau during the middle Miocene climate transition (Abrajevitch et al., 2014).

\subsubsection{Iron export}

Downward $\mathrm{Fe}$ and $\mathrm{C}$ fluxes were measured directly in freefloating sediment P-traps at the plateau (A3-2) and plume (E-1, E-3, E-5) stations and estimated using the ${ }^{234}$ Th fluxes and $\mathrm{Fe} / \mathrm{Th}$ ratios at the reference site (R-2) (Planchon et al., 2015). The sinking of $\mathrm{pFe}$ was by far the greatest loss term in our budgets, with $5746 \mathrm{nmol} \mathrm{m}^{-2} \mathrm{~d}^{-1}$ of total Fe exported from the mixed layer on the plateau, between 895 and $4579 \mathrm{nmol} \mathrm{m}^{-2} \mathrm{~d}^{-1}$ exported at the plume stations and $1302 \mathrm{nmol} \mathrm{m}^{-2} \mathrm{~d}^{-1}$ exported at the reference station. The flux of sinking pFe decreased from station E-1 to E-3 to E5 , concurrent with the seasonal progression of the bloom and indicating the mixed layer assemblages were efficiently recycling Fe under strong grazing pressure (Laurenceau-Cornec et al., 2015). The downward total $\mathrm{pFe}$ fluxes were greater than the sum of the vertical, lateral and atmospheric dFe supply on the plateau but were generally less in the plume.

Aluminium was used as a normaliser to estimate the fraction of lithogenic $\mathrm{Fe}$ in the exported material. The percentage lithogenic fraction of total $\mathrm{pFe}$ exported at the $\mathrm{E}$ stations remained much the same at each deployment (34-39\%), whereas the lithogenic fraction was a much larger component at A3-2 (51\%), reflecting the close proximity to sources of particulate material rich in $\mathrm{Fe}$. The $\mathrm{Fe} / \mathrm{Al}$ ratio of exported material was higher at $\mathrm{E}$ stations (1.0-1.1) and on the plateau A3-2 (0.87) compared to the $\mathrm{Fe} / \mathrm{Al}$ ratio of lithogenically dominated particles (0.2; Wedepohl, 1995), confirming that a significant amount of exported $\mathrm{Fe}$ was biogenic in origin.
Interestingly, the $\mathrm{Fe} / \mathrm{Al}$ export ratios were similar to those associated with suspended particles at E stations (0.9-1.2) but lower than the $\mathrm{Fe} / \mathrm{Al}$ of suspended particles at A3-2 (1.2). This suggests that the biota associated with the plateau bloom at A3 were more capable of efficiently recycling and retaining biogenic particulate $\mathrm{Fe}$ in the mixed layer (through rapid turnover to prevent aggregation and sinking) compared to lithogenic particulate $\mathrm{Fe}$, which had a shorter residence time and was preferentially exported to depth. This may be due to greater ballasting of the lithogenic particles (Ellwood et al., 2014) and is consistent with other export studies which have shown that biologically processed particles have longer residence times than lithogenic particles in the mixed layer (Lamborg et al., 2008a). Since P may be lost from exported particles much faster than $\mathrm{Fe}$ due to bacterial remineralisation and zooplankton consumption (Schneider et al., 2003; Lamborg et al., 2008b), it was not appropriate to apply a biogenic normaliser to the P-trap data as this may underestimate the biogenic Fe component of particles captured in the traps.

Iron export fluxes were greater during the spring study of KEOPS- 2 compared to the late summer study of KEOPS- 1 (Table 2). This difference between the KEOPS studies was also observed in Fe uptake rates (Fourquez et al., 2015). Such observations may be simply related to the seasonal supply; in other words, greater Fe supply in spring resulted in greater Fe uptake and export. Determined $\mathrm{pFe}$ sinking fluxes were also greater than those observed during CROZEX study (Planquette et al., 2011), the SAZ-Sense expedition south of Tasmania (Bowie et al., 2009) and the FeCycle-I expedition east of New Zealand (Frew et al., 2006) and of similar magnitude to those reported by Bowie et al. (2001) during the Southern Ocean Iron Release Experiment (SOIREE ) $\left(5.2 \mu \mathrm{mol} \mathrm{m}^{-2} \mathrm{~d}^{-1}\right)$, but they were much lower than Ellwood et al. (2014) reported for FeCycle-II.

The export of particulate organic carbon (POC) into our Ptraps followed the same trend as that of $\mathrm{pFe}$ at the $\mathrm{E}$ stations, decreasing from $7.0 \pm 2.3$ at E-1 to $2.0 \pm 1.0 \mathrm{mmol} \mathrm{m}^{-2} \mathrm{~d}^{-1}$ at E-5 (Table 1). Despite the higher pFe vertical fluxes at A3-2, POC export was lower than the E stations. The C export fluxes at $200 \mathrm{~m}$ at A3-2 using our P-traps (LaurenceauCornec et al., 2015) were similar to results estimated from ${ }^{234} \mathrm{Th}$ deficits by Planchon et al. $(2015 ; 2.3 \pm 0.7$ and $3.8 \pm 0.8 \mathrm{mmol} \mathrm{C} \mathrm{m}^{-2} \mathrm{~d}^{-1}$, respectively). The comparison of these POC fluxes to results (for the A3 plateau site only) obtained during KEOPS-1 illustrates highly dynamic variations, reflecting the rapid decline in biomass during autumn (Blain et al., 2007). Specifically, P-trap measurements of POC fluxes at $200 \mathrm{~m}$ during KEOPS- 1 decreased from $3.7 \pm 0.3$ to $1.3 \pm 0.3 \mathrm{mmol} \mathrm{C} \mathrm{m}^{-2} \mathrm{~d}^{-1}$ over two visits to A3 in February 2005 (Trull et al., 2008), whereas estimates based on ${ }^{234} \mathrm{Th}$ at this time, reflecting the previous $\sim 30$ days of export, suggested much higher values $(25 \pm 7 \mathrm{mmol}$ $\mathrm{C} \mathrm{m}^{-2} \mathrm{~d}^{-1}$; Savoye et al., 2008). These variations illustrate the difficulty of constraining budgets in temporally evolving systems, providing a cautionary note to our efforts. Addi- 
tional discussion of temporal and spatial export flux variations during KEOPS-2 is provided in Laurenceau-Cornec et al. (2015) and Planchon et al. (2015).

\subsubsection{Biological iron recycling}

Intracellular $\mathrm{Fe}$ uptake by phytoplankton and bacteria $>0.2 \mu \mathrm{m}$ (Fourquez et al., 2015) was measured at stations A3-2 and E-5 when the bloom was rapidly growing (Cavagna et al., 2014). Iron uptake fluxes were similar on both the plateau (A3-2) and in the plume (E-5), ranging between 1120 and $1745 \mathrm{nmol} \mathrm{m}^{-2} \mathrm{~d}^{-1}$. If we assume that the Fe uptake rate of $28.1 \mathrm{pmol} \mathrm{L}^{-1} \mathrm{~d}^{-1}$ measured at E-5 (Fourquez et al., 2015) was conservative at $\mathrm{E}$ stations, $0.17 \mathrm{nmol} \mathrm{L}^{-1}$ of Fe could have been consumed in surface waters between the occupations of stations E-4E and E-5. This is consistent with the observed decrease in surface dFe concentrations from 0.19 to $0.06 \mathrm{nmol} \mathrm{L}^{-1}$ at E-4E and E-5, respectively (F. Quéroué, personal communication, 2013). The net and gross demand calculated at A3 during KEOPS-1 (204 and $408 \mathrm{nmol} \mathrm{m}^{-2} \mathrm{~d}^{-1}$, respectively; Sarthou et al., 2008) is approximately 3-5 times smaller than the intracellular Fe uptake at A3-2 during KEOPS-2 for a similar C biomass (mean value of 12.7 and $10.3 \mu \mathrm{mol} \mathrm{L}{ }^{-1}$ POC in surface at KEOPS1 and KEOPS-2, respectively; Cavagna et al., 2014), perhaps indicating luxury uptake as well as important differences in community composition and activity (primary production). These studies provide the opportunity to compare KEOPS-2 to KEOPS-1 data and generate a general picture of the seasonal progress from early spring to late summer, assuming that interannual and spatial variability is low, which may not be the case (Grenier et al., 2015).

The bacterial and mesozooplankton contributions to Fe regeneration were calculated separately (Table 3). Volumetric values varied between 0.06 and $0.59 \mathrm{pmol} \mathrm{Fe} \mathrm{L}^{-1} \mathrm{~d}^{-1}$ and between 0.02 and 0.08 pmol Fe $\mathrm{L}^{-1} \mathrm{~d}^{-1}$ for bacterial and mesozooplankton Fe regeneration, respectively. The mesozooplankton rates were much lower than for KEOPS-1 because there were much fewer individuals $(0.26-0.56$ per L, compared to about 1-6 individuals per L for KEOPS-1; see Fig. 2 in Carlotti et al., 2008). Total Fe regeneration fluxes ranged from $10(\mathrm{R}-2)$ to $71(\mathrm{~A} 3-2) \mathrm{nmol} \mathrm{m}^{-2} \mathrm{~d}^{-1}$.

A similar $\mathrm{Fe}$ regeneration calculation was also performed based on the $\mathrm{C}$ budget by using the percentage of gross community production (GCP) that is remineralised for KEOPS2 and results from Fe uptake experiments described above. This yielded higher Fe regeneration estimates in the range of $1-11 \mathrm{pmol} \mathrm{L}^{-1} \mathrm{~d}^{-1}$. Specifically, for station A3-2, $23 \%$ of GCP was remineralised, and therefore the Fe regeneration flux in the mixed layer was $1119 \mathrm{nmol} \mathrm{m}^{-2} \mathrm{~d}^{-1}$. Similarly, for station E-5, $34 \%$ of GCP was remineralised, resulting in an Fe regeneration flux of $504 \mathrm{nmol} \mathrm{m}^{-2} \mathrm{~d}^{-1}$. Since the Fe regeneration fluxes based on the $\mathrm{C}$ budget are much greater ( $\sim 16$ times) than those calculated using the first approach, this suggests that the remineralisation efficiency for Fe regeneration appears to be less than that of $\mathrm{C}$.

Iron regeneration fluxes can be compared with those from KEOPS-1 using the same first approach above. For station A3 on KEOPS-1, this resulted in a Fe regeneration flux of 1 pmol L ${ }^{-1} \mathrm{~d}^{-1}$ in surface waters. Malits et al. (2014) also calculated the release of bacterial bound $\mathrm{Fe}$ by viral lysis $\left(0.42 \mathrm{pmol} \mathrm{L}^{-1} \mathrm{~d}^{-1}\right)$, which was the dominant loss term during KEOPS-1 (Brussaard et al., 2008). This value compared to 1.5 pmol $\mathrm{L}^{-1} \mathrm{~d}^{-1}$ determined in zooplankton grazing experiments (Sarthou et al., 2008), suggesting that grazing and microbial Fe cycling were in a similar range, and the total $\mathrm{Fe}$ regeneration was between $2-3$ pmol L ${ }^{-1} \mathrm{~d}^{-1}$ for KEOPS-1.

Importantly, $\mathrm{Fe}$ regeneration was much lower during the early compared to late bloom stage and was dominated by bacterial regeneration in spring (60-90\% of total Fe regeneration). Strzepek et al. (2005) estimated Fe regeneration rates (during FeCycle-II) for herbivores (16.518.4 pmol L $\left.{ }^{-1} \mathrm{~d}^{-1}\right)$, bacterivores $\left(15-25.5 \mathrm{pmol} \mathrm{L}^{-1} \mathrm{~d}^{-1}\right)$ and viruses $\left(0.4-28 \mathrm{pmol} \mathrm{L}^{-1} \mathrm{~d}^{-1}\right)$, which is equivalent to a total Fe regeneration rate of $1435-3236 \mathrm{nmol} \mathrm{m}^{-2} \mathrm{~d}^{-1}$ for a $45 \mathrm{~m}$ mixed layer. Bowie et al. (2009) estimated Fe regeneration to be $261-1206 \mathrm{nmol} \mathrm{m}^{-2} \mathrm{~d}^{-1}$ for the SAZ-Sense study. So our determined KEOPS-2 mixed-layer Fe regeneration rates ( 71 and $31 \mathrm{nmol} \mathrm{m}^{-2} \mathrm{~d}^{-1}$ at A3-2 and E-5, respectively) were on the lower end of the range reported in other sectors of the Southern Ocean, and clearly insufficient to meet demand (measured as Fe uptake) at all stations, indicating a reliance on new Fe supply. This is discussed in more detail below.

\subsection{Sequestration efficiencies: iron-to-carbon ratios}

The mixed-layer phytoplankton intracellular Fe / C uptake ratios were calculated directly from deck board incubations for stations A3-2 (0.007 mmol mol$\left.{ }^{-1}\right)$ and E-5 (0.021 mmol $\mathrm{mol}^{-1}$ ) (Table 1). These values are similar to those reported for other natural and artificial iron fertilisation studies in the Southern Ocean, including for Fe-limited conditions during the Southern Ocean Iron Experiment (SOFeX; $0.01 \mathrm{mmol}$ $\mathrm{mol}^{-1}$; Twining et al., 2004), and those inside the KEOPS1 plateau bloom $\left(0.005 \mathrm{mmol} F \mathrm{Fe}^{-1}\right.$; Sarthou et al., 2008) but lower than those reported for SAZ-Sense (0.06$0.07 \mathrm{mmol} \mathrm{mol}^{-1}$; Bowie et al., 2009).

Suspended mixed layer $\mathrm{Fe} / \mathrm{C}$ ratios (Table 1) were significantly higher than phytoplankton intracellular uptake ratios. This finding is likely the result of the contribution of lithogenic and detrital $\mathrm{Fe}$ to suspended material $\mathrm{Fe} / \mathrm{C}$ ratios and is consistent with the removal of $\mathrm{C}$ at a faster rate than that of $\mathrm{Fe}$ and with Fe being added through new sources after phytoplankton uptake. Differences may also arise because of luxury uptake, the timescale of integration in deck board experiments compared to $\mathrm{Fe} / \mathrm{C}$ ratios in ocean suspended and sinking particles (which are broadly similar - see below), and/or the fact that our system was not in steady state. 
Table 2. Fluxes of iron and carbon (mean and standard deviation, SD) exported in sinking particles (trap deployed at $200 \mathrm{~m}$ ) and ratio of $\mathrm{Fe} / \mathrm{C}$ in sinking (traps) and suspended mixed layer (ISP) particles at stations A3-2 and E-stations. There was no successful trap deployment at station R-2. A comparison to previous studies is provided.

\begin{tabular}{|c|c|c|c|c|c|c|c|}
\hline \multirow[t]{2}{*}{ Site } & \multicolumn{2}{|c|}{$\begin{array}{l}\text { PFe flux } \\
\left(\mu \mathrm{molm} \mathrm{m}^{-2} \mathrm{~d}^{-1}\right)\end{array}$} & \multicolumn{2}{|c|}{$\begin{array}{l}\text { POC flux } \\
\left(\mathrm{mmolm}^{-2} \mathrm{~d}^{-1}\right)\end{array}$} & \multicolumn{2}{|c|}{$\begin{array}{l}\mathrm{Fe} / \mathrm{C}(\text { sinking }) \\
\left(\mathrm{mmol} \mathrm{mol}^{-1}\right)\end{array}$} & \multirow{2}{*}{$\begin{array}{l}\mathrm{Fe} / \mathrm{C}(\text { suspended }) \\
(\mathrm{mmol} \mathrm{mol}-1) \\
\text { mean }\end{array}$} \\
\hline & mean & SD & mean & SD & mean & SD & \\
\hline \multicolumn{8}{|l|}{ KEOPS-2 } \\
\hline A3-2 & 5.75 & 1.20 & 2.23 & 0.68 & 2.57 & 0.97 & 1.51 \\
\hline E-1 & 4.58 & 1.38 & 7.02 & 2.28 & 0.65 & 0.52 & 0.49 \\
\hline E-3 & 1.89 & 0.29 & 4.87 & 1.54 & 0.39 & 0.29 & 0.39 \\
\hline E-5 & 0.90 & 0.36 & 2.00 & 1.00 & 0.45 & 0.13 & 0.33 \\
\hline \multicolumn{8}{|l|}{ KEOPS-1 1} \\
\hline A3-initial & 0.33 & 0.05 & 3.60 & 0.43 & 0.09 & - & - \\
\hline A3-final & 0.20 & 0.02 & 1.36 & 0.39 & 0.15 & - & - \\
\hline $\mathrm{C} 5$ & 1.51 & 0.32 & 1.57 & 0.08 & 0.96 & - & - \\
\hline \multicolumn{8}{|l|}{ CROZEX $^{2}$} \\
\hline North & 0.84 & - & 15.9 & - & 2.55 & - & 0.69 \\
\hline South & 0.23 & - & 12.9 & - & 0.57 & - & 0.31 \\
\hline \multicolumn{8}{|l|}{ SAZ-Sense ${ }^{3}$} \\
\hline $\mathrm{P} 1$ & 0.17 & 0.09 & 3.34 & 1.81 & 0.05 & 0.04 & 0.04 \\
\hline $\mathrm{P} 2$ & 0.07 & 0.01 & 2.11 & 0.88 & 0.04 & 0.02 & 0.06 \\
\hline $\mathrm{P} 3$ & 0.21 & 0.05 & 0.86 & 0.38 & 0.25 & 0.13 & 0.03 \\
\hline \multicolumn{8}{|l|}{ FeCycle-1 4} \\
\hline $\mathrm{F} 1-80 \mathrm{~m}$ & 0.22 & 0.03 & n.d. & - & n.d. & - & 0.04 \\
\hline $\mathrm{F} 1-120 \mathrm{~m}$ & 0.36 & 0.05 & 2.09 & 0.03 & 0.17 & - & - \\
\hline $\mathrm{F} 2-80 \mathrm{~m}$ & 0.55 & 0.06 & 2.51 & 0.17 & 0.22 & - & - \\
\hline $\mathrm{F} 2-120 \mathrm{~m}$ & 0.35 & 0.03 & 2.10 & 0.01 & 0.17 & - & - \\
\hline \multicolumn{8}{|l|}{ FeCycle-2 5} \\
\hline A1-100 m & 5.0 & 0.7 & 11 & - & 0.45 & - & 0.78 \\
\hline A1-200 m & 7.3 & 1.6 & 5.8 & - & 1.26 & - & - \\
\hline $\mathrm{A} 2-100 \mathrm{~m}$ & 10 & 1.0 & 42 & - & 0.24 & - & 1.12 \\
\hline A2-200 m & 10 & 9 & 6.8 & 1.8 & 1.47 & - & - \\
\hline A3-100 m & 17 & 2 & 12 & 2 & 1.42 & - & 0.63 \\
\hline A3-200 m & 10 & 1 & 14 & - & 0.71 & - & - \\
\hline A4-100 m & 20 & 8 & 9.3 & 0.9 & 2.15 & - & 0.86 \\
\hline A4-200 m & 15 & 6 & 6.1 & 1.8 & 2.46 & - & - \\
\hline \multicolumn{8}{|l|}{ Other literature data } \\
\hline Mixed plankton assemblages 6 & - & - & - & - & - & - & $0.01-0.05$ \\
\hline Iron-limited algae $^{7}$ & - & - & - & - & - & - & 0.01 \\
\hline Iron-replete algae ${ }^{7}$ & - & - & - & - & - & - & $0.02-0.05$ \\
\hline Southern Ocean synthesis 8 & - & - & - & - & $0.01-0.06$ & - & - \\
\hline
\end{tabular}

n.d.: no data

${ }_{1}^{1}$ Data for particles $>0.2 \mu \mathrm{m}$ (Blain et al., 2007; Bowie et al., unpublished data).

2 Data for $>53 \mu \mathrm{m}$ particles only (Planquette et al., 2011). Downward Fe fluxes were estimated from samples collected from in situ pumps using

${ }^{234} \mathrm{Th}$ depletions and $\mathrm{Fe} / \mathrm{Th}$ ratios in sinking particles. Waters to the north of Crozet Island were downstream of the islands and iron fertilised, whilst those to the south were upstream HNLC conditions. The $\mathrm{Fe} / \mathrm{C}$ from bioassay culturing experiments conducted during CROZEX was

$0.25 \mathrm{mmol} \mathrm{mol}^{-1}$ (Moore et al., 2008).

${ }^{3}$ Data for particles $>1 \mu \mathrm{m}$ (Bowie et al., 2009).

${ }^{4}$ Data for particles $>0.4 \mu \mathrm{m}$ (Frew et al., 2006). Only one mixed layer Fe/C ratio was reported. The biogenic $\mathrm{Fe} / \mathrm{C}$ mixed layer ratio was estimated to be $0.004-0.012 \mathrm{mmol} \mathrm{mol}^{-1}$.

${ }^{5}$ Data for particles $>0.4 \mu \mathrm{m}$, except deployment A1 (>2 $\mu \mathrm{m}$ ) (Ellwood et al., 2014). The mixed layer Fe/C ratios were calculated from Table 4 using the sediment trap deployment periods reported in Table 3 in the original publication.

${ }^{6}$ Estimates of $\mathrm{Fe} / \mathrm{C}$ for diatoms and whole plankton assemblages compiled by de Baar et al. (2008), with optimal ratios for growth tending towards the upper end of the range.

${ }^{7}$ Intracellular ratio reported for HNLC polar water south of New Zealand during SOFeX (Twining et al., 2004).

${ }^{8}$ Ratio of dFe supply to POC export, synthesis by Morris and Charette (2013). 
Table 3. Iron regeneration rates based on bacterivore and herbivore contributions.

\begin{tabular}{lccccc}
\hline Site & $\begin{array}{c}\text { Bacterial } \\
\left(\mathrm{pmolL}^{-1} \mathrm{~d}^{-1}\right)\end{array}$ & $\begin{array}{c}\text { Mesozooplankton } \\
\left(\mathrm{pmol} \mathrm{L}^{-1} \mathrm{~d}^{-1}\right)\end{array}$ & $\begin{array}{c}\text { Total Fe } \\
\text { regeneration } \\
\left(\mathrm{pmol} \mathrm{L}^{-1} \mathrm{~d}^{-1}\right)\end{array}$ & $\begin{array}{c}\text { Percentage bacterial } \\
\text { contribution }\end{array}$ & $\begin{array}{c}\text { Total integrated } \\
\text { mixed layer Fe } \\
\text { regeneration } \\
\left(\mathrm{nmol} \mathrm{m}^{-2} \mathrm{~d}^{-1}\right)\end{array}$ \\
\hline R-2 & $0.06 \pm 0.01$ & 0.04 & 0.10 & 61 & 10 \\
A3-1 & $0.10 \pm 0.03$ & 0.02 & 0.12 & 87 & 19 \\
A3-2 & $0.43 \pm 0.07$ & 0.03 & 0.46 & 93 & 71 \\
E-1 & $0.33 \pm 0.02$ & 0.04 & 0.37 & 88 & 27 \\
E-3 & $0.54 \pm 0.04$ & 0.06 & 0.60 & 90 & 23 \\
E-5 & $0.59 \pm 0.03$ & 0.08 & 0.67 & 88 & 31 \\
\hline
\end{tabular}

Also, since a Ti-citrate-EDTA wash was used to remove extracellular surface Fe during the incubation experiments but not from particles collected in the ISPs and P-traps, our suspended and sinking $\mathrm{pFe}$ concentrations include $\mathrm{Fe}$ present within cells, adsorbed to cell walls, detrital Fe and lithogenic $\mathrm{Fe}$. This would tend to increase $\mathrm{Fe} / \mathrm{C}$ in suspended particles. Differences between intracellular and suspended mixed-layer $\mathrm{Fe} / \mathrm{C}$ ratios may also derive from the $\mathrm{C}$ term, since the ISP sampling includes detrital material as well as living cells. We also note that suspended $\mathrm{pFe}$ data are the sum of 1-53 and $>53 \mu \mathrm{m}$ size fractions collected by ISPs and thus may also include some sinking particles. This may affect the suspended $\mathrm{Fe} / \mathrm{C}$ ratios.

In addition to the ratio of "total" particulate (biogenic + lithogenic) Fe over POC ( $\mathrm{Fe} / \mathrm{C})$ in suspended particles discussed above, we also calculated the ratio of biogenic $\mathrm{Fe}$ over POC (i.e. $\mathrm{Fe}_{\text {bio }} / \mathrm{C}$ ) following methods discussed in Sect. 3.2.1. Profiles are shown in Fig. 5. Suspended Fe / C ratios were remarkably similar at all E stations and station R-2 but higher on the plateau at A3 stations (Table 1). We also observed generally surface-to-deep increases in $\mathrm{Fe} / \mathrm{C}$ ratios in suspended particles at all stations (Fig. 5), consistent with earlier findings (Frew et al. 2006). The vertical profiles of $\mathrm{Fe}_{\text {bio }}$ / C showed a similar structure at the three study sites, with a general decreasing trend from the surface to sea floor (opposite to that of $\mathrm{Fe} / \mathrm{C}$ ); note that a constant $\mathrm{Fe} / \mathrm{P}$ was used to estimate the $\mathrm{Fe}_{b i o}$ component. These findings indicate that $\mathrm{Fe}$ is preferentially retained within, and adsorbed to, sinking particles (i.e. scavenging drives the total $\mathrm{Fe} / \mathrm{C}$ ratio), but biogenic $\mathrm{Fe}$ is recycled at a faster rate compared to $\mathrm{C}$, similar to macronutrients $\mathrm{N}$ and $\mathrm{P}$. A preferential loss of $\mathrm{C}$ relative to $\mathrm{Fe}$ from sinking material implies that an external input of $\mathrm{Fe}$ is required to sustain a downward flux of carbon.

At station $\mathrm{R}-2$, the $\mathrm{Fe} / \mathrm{C}$ ratio peaked at $500 \mathrm{~m}$, most likely due to lithogenic particulate Fe input (and not $\mathrm{C}$ ) from the Leclaire Rise (see above) (note this peak was not seen in the $\mathrm{Fe}_{\text {bio }} / \mathrm{C}$ ratios). At $\mathrm{E}$ stations, the $\mathrm{Fe} / \mathrm{C}$ ratio showed maximum values in mesopelagic intermediate waters in the $600-1000 \mathrm{~m}$ depth range. We also believe this was due to the lateral transport of lithogenic particulate $\mathrm{Fe}$ (and not C) from the plateau (seafloor at $\sim 600 \mathrm{~m}$ ) into the plume. This is supported by the absence of this feature in the $\mathrm{Fe}_{\text {bio }} / \mathrm{C}$ ratios for $\mathrm{E}$ stations. $\mathrm{Fe} / \mathrm{C}$ ratios in deep waters were much higher at $\mathrm{A} 3$ stations $\left(26-38 \mathrm{mmol} \mathrm{mol}^{-1}\right.$ ) compared to R-2 $\left(4 \mathrm{mmol} \mathrm{mol}^{-1}\right)$ and $\mathrm{E}$ stations $\left(5-7 \mathrm{mmol} \mathrm{mol}^{-1}\right)$, indicating enrichment of lithogenic particulate $\mathrm{Fe}$ above the plateau. Some fraction of this lithogenic Fe will be accessible to the biota and then be incorporated into the biogenic Fe pool. This is confirmed by modification in the $\mathrm{Fe} / \mathrm{Al}$ ratio (van der Merwe et al., 2015). Inclusion of the biologically available fraction of the lithogenic Fe flux is therefore required to calculate fully the yield of carbon exported per unit $\mathrm{Fe}$ injected, consistent with Planquette et al. (2011) and Pollard et al. (2009).

Interestingly, although $\mathrm{Fe} / \mathrm{C}$ ratios varied greatly between stations $\left(0.2-37 \mathrm{mmol} \mathrm{mol}^{-1}\right)$, the $\mathrm{Fe}_{\text {bio }} / \mathrm{C}$ ratio

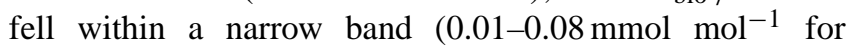
all stations and depths), which encompasses the elemental ratios of Fe-replete $\left(0.04 \mathrm{mmol} \mathrm{mol}^{-1}\right)$ and Fe-limited $\left(0.01 \mathrm{mmol} \mathrm{mol}^{-1}\right)$ large diatoms (Sunda and Huntsman, 1995; de Baar et al., 2008). This highlights the tight coupling between $\mathrm{Fe}_{\text {bio }}$ and POC in the absence of new sources of $\mathrm{Fe}$ and allow us to estimate the relative remineralisation efficiencies for $\mathrm{Fe}$ versus $\mathrm{C}$. The $\mathrm{Fe}_{\text {bio }} / \mathrm{C}$ data contrast with the findings of Planquette et al. (2011) for the CROZEX study who observed variable $\mathrm{Fe}_{\text {bio }}$ / $\mathrm{C}$ ratios to the north of Crozet (Fe-fertilised region), which were on average much higher than those found to the south (Fe-limited region). The fraction of $\mathrm{Fe}_{\text {bio }}$ relative to lithogenic $\mathrm{Fe}$ in particles collected below the mixed layer also depends on the stage of the bloom, the nature and magnitude of the supply of new lithogenic particles, and the rate of conversion from lithogenic-to-biogenic Fe (Lam et al., 2006; Frew et al., 2006; Lam and Bishop, 2008). These factors are highly variable in the Kerguelen region and this explains the wide range of $\mathrm{Fe}_{\text {bio-to-total }} \mathrm{Fe}$ values in particles observed during KEOPS-2.

The $\mathrm{Fe} / \mathrm{C}$ export ratio of sinking particles in our traps were similar to suspended mixed-layer ratios for the E stations but slightly higher at A3-2 (Fig. 5), possibly due to the sinking of recently supplied lithogenics over the plateau. 


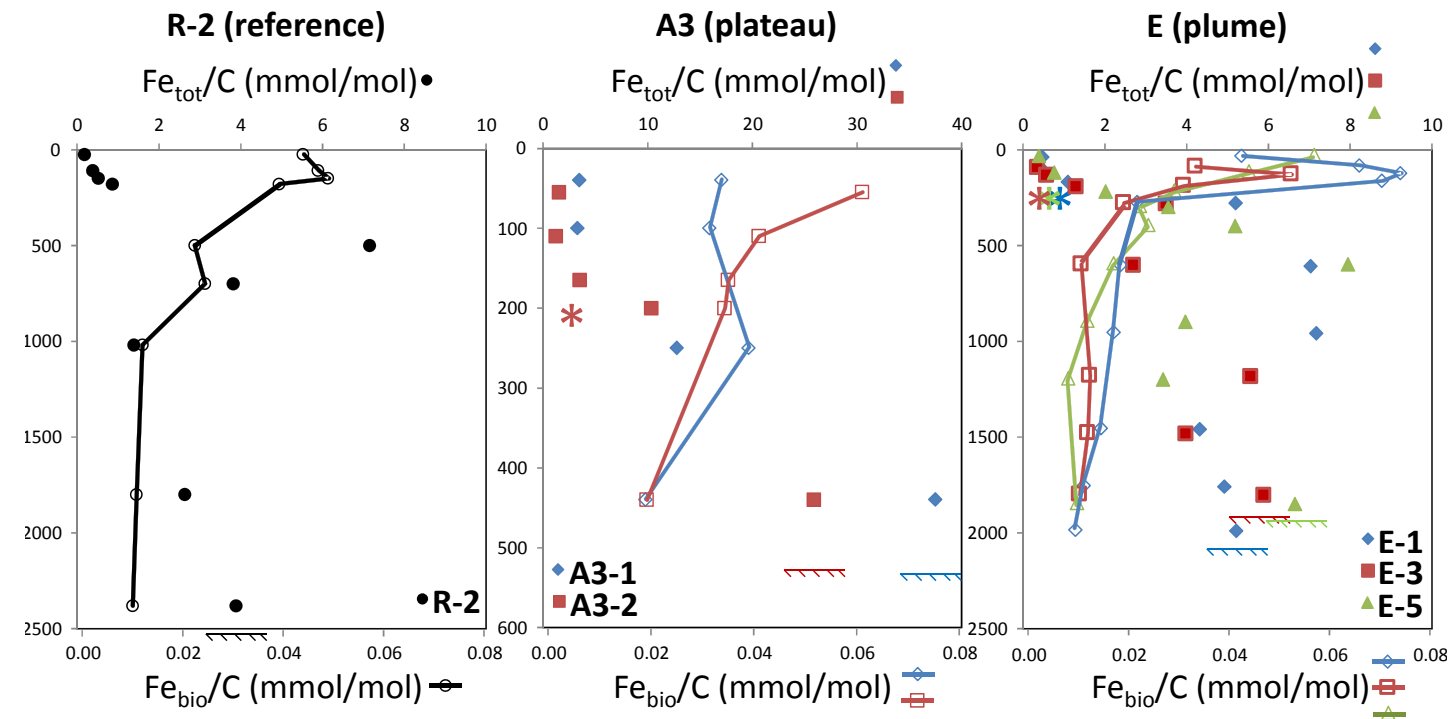

Figure 5. Vertical profiles of Fe / C ratios in suspended (ISP) and sinking (P-trap) particles. Solid symbols indicate total Fe / C (i.e. ratio of biogenic + lithogenic Fe over POC) and joined open symbols indicate $\mathrm{Fe}_{\text {bio }} / \mathrm{C}$ (i.e. ratio of biogenic Fe only over POC; calculated using P as a normaliser). The asterisk markers $\left(^{*}\right)$ show the export total Fe / C ratio (P-traps). Note the different scale on the $x$ axis for Fe / $\mathrm{C}$ at $\mathrm{A} 3$ stations.

Both $\mathrm{pFe}$ and POC export fluxes decreased during bloom development at $\mathrm{E}$ stations, indicating the mixed layer became more retentive for both $\mathrm{Fe}$ and $\mathrm{C}$. This is consistent with the picture that emerges from the $\mathrm{E}$ time series from primary and export production estimates, which show that production was moderate and matched by the moderate export during our visits (Planchon et al., 2015; Trull et al., 2015; Cavagna et al., 2014).

Since POC export fluxes during spring (KEOPS-2) were similar to late summer (KEOPS-1), but $\mathrm{pFe}$ export fluxes were higher in spring compared to summer (Table 2), this resulted in a generally higher carbon sequestration efficiency (lower $\mathrm{Fe} / \mathrm{C}$ ) during late summer, consistent with a rapidly exporting ecosystem during bloom decline. The exported particles may have been dominated by more lithogenics and may have been much more processed in KEOPS- 2 compared to KEOPS-1, where the system had already run out of Fe. It was also expected that growing communities during KEOPS2 would retain $\mathrm{dFe}$ through luxury uptake, which may also result in observed generally higher $\mathrm{Fe} / \mathrm{C}$ ratios in sinking particles during the spring bloom (KEOPS-2, FeCycle-II) compared to austral summer conditions (KEOPS-1, CROZEX, FeCycle-I; Blue Water Zone; Morris and Charette, 2013) (Table 2 and Fig. 6).

Morris and Charette (2013) presented a detailed synthesis of ${ }^{234} \mathrm{Th}$-derived POC export and dFe budgets in studies where natural iron fertilisation fuels the substantial phytoplankton blooms observed in the Southern Ocean. Where data are available to calculate the seasonal $\mathrm{Fe} / \mathrm{C}$ ratios, 1 order of magnitude variation (0.006-0.06) is observed between different Southern Ocean regions. It is likely that $\mathrm{Fe} / \mathrm{C}$ ra- tio variations (Table 2) reflect both experimental methodologies, different calculation approaches, observational limitations and system complexities. Le Moigne et al. (2014) have also recently shown that variability in the carbon sequestration efficiency is related to the mode of Fe delivery.

\subsection{Iron supply vs. demand}

Using calculated flux estimates, a comparison of Fe supply and demand at the three sites around the Kerguelen Archipelago in spring was possible (Fig. 7). In our shortterm iron biogeochemical budgets, the total dFe supply from new sources (calculated as the sum of diffusion, upwelling, vertical and lateral advection, and atmospheric dust) to surface waters of the plume was more than twice that above the plateau and $>20$ times greater than at the reference station (Table 1). The Fe demand (measured by cellular Fe uptake) in the plume was similar (1.5 times greater) to the plateau but $>40$ times greater than at the reference station. New Fe supply was 14-94 times greater than recycled Fe supply ("iron remineralisation"; row i in Table 1) from bacterial regeneration and zooplankton grazing. This contrasts with the findings of Bowie et al. (2009) for SAZ-Sense who reported recycled fluxes that were broadly comparable with new Fe supply in the SAZ in summer at study sites further from natural iron fertilisation.

Since Fe supply from new sources was greater than the $\mathrm{Fe}$ demand (uptake minus remineralisation as a recycled $\mathrm{Fe}$ source) at all stations (R-2, A3-2 and E-5), this resulted in a positive value for row $\mathrm{k}$ in Table 1 (i.e. there was no additional $\mathrm{Fe}$ required to balance the dissolved budget). This find- 


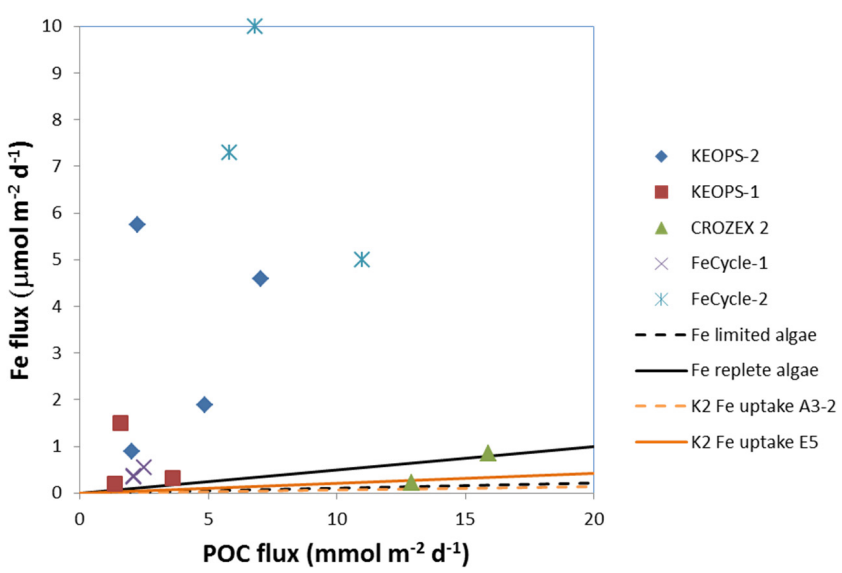

Figure 6. A comparison of export fluxes of $\mathrm{pFe}$ versus POC in sinking particles for natural iron fertilisation studies in the Southern Ocean. For details of the sampling methods, refer to Table 2 and the original articles. The lines indicate $\mathrm{Fe} / \mathrm{C}$ ratios for $\mathrm{Fe}$-limited (black dashed) and Fe-replete (black solid) phytoplankton (Twining et al., 2004) and the mean mixed-layer intracellular $\mathrm{Fe} / \mathrm{C}$ ratios at stations A3-2 (orange dashed) and E5 (orange solid) on KEOPS2 (taken from Table 1). FeCycle-II had complex biogeochemical dynamics due to a storm event and subsequent deep-water mixing (during sediment trap deployment at their station A3), splitting the study into two phases ("eddy centre" and "eddy periphery"). To aid interpretation of $\mathrm{Fe} / \mathrm{C}$ export data in the context of iron fertilisation, only data from the pseudo-Lagrangian phase 1 (i.e. deployments A1 and A2 during bloom development and export) from that study are included in this plot (Ellwood et al., 2014).

ing is consistent with other observations at both the plateau and plume sites which were Fe replete in early spring but somewhat surprising for the HNLC reference site R-2. This may partly be a result of an overestimate of the atmospheric supply used in calculations presented here from literature data. Another explanation is that the parameters used in our "short-term" iron budget calculations are decoupled in time (e.g. there will be an offset between the mechanisms for organism acquisition of $\mathrm{Fe}$ and the processes resulting in $\mathrm{Fe}$ laden particles leaving the upper ocean), and the short-term Fe budget is based on an "instantaneous picture" of different fluxes that were not in steady state.

Interestingly, at station A3-2, the sink processes (Fe export and uptake) are so large and the regenerated $\mathrm{Fe}$ flux so small that the total (dissolved + particulate) Fe losses are far greater than the net dFe supply (Fig. 7a). In other words, to a first order the budget is not balanced with known sources of $\mathrm{Fe}$ insufficient to account for the downward flux, even if we only accounted for the non-lithogenic particulate Fe export flux (row 1 in Table 1). Assuming all flux calculations to be correct within the estimated error bounds in Table 1, this implies that there is a missing flux term in the budget at A3 and this is likely lithogenic pFe from the Kerguelen Plateau and/or Heard Island (and this may be converted to biogenic $\mathrm{Fe}$ ). Currently, we do not invoke a lithogenic pFe to $\mathrm{dFe}$ transfer in the budget, which could increase the $\mathrm{Fe}$ supply on the plateau significantly, although at present we do not know what fraction of particulate material is converted into the dissolved form. This will vary largely with the mineralogy (Schroth et al., 2009), provenance of the particles and seawater characteristics (e.g. organic complexation; Shaked and Lis, 2012). Indeed, Thuróczy et al. (2012) previously measured organic complexation in Antarctic waters and discussed the role of ligands in transporting and dissolving $\mathrm{pFe}$ into $\mathrm{dFe}$, using theoretical data provided by Borer et al. (2005).

Applying a solubility of $2.5 \%$ used for KEOPS- 1 at A3 to enable Fe supply to meet demand (Blain et al., 2007) would provide an extra $10-34 \mu \mathrm{mol} \mathrm{m}^{-2}$ of $\mathrm{dFe}$ to the mixed layer over the plateau in KEOPS-2, approximately doubling the $\mathrm{dFe}$ standing stock. These values are comparable to our observations and suggest that particulate material plays a major role in the supply of dFe (van der Merwe et al., 2015). Further, if we assume $\mathrm{pFe}$ from glacial melt is delivered over a 3-month period, this would provide an additional 111$387 \mathrm{nmol} \mathrm{m}^{-2} \mathrm{~d}^{-1}$ to the mixed layer at A3, values of similar magnitude to the individual vertical and lateral supply terms. Whilst a dissolution estimate of $2.5 \%$ may be considered to be at the upper extent of the range, Schroth et al. (2009) have reported that $2-3 \%$ of $\mathrm{Fe}$ is soluble in glacial flour, which can remain suspended in surface water for several months after delivery from the Kerguelen or Heard islands.

The release of Fe to biota via the conversion of lithogenic to biogenic $\mathrm{Fe}$ has been previously suggested (Lam et al., 2006; Frew et al., 2006; Borer et al., 2009; Planquette et al., 2011) and the present work strongly supports this hypothesis, with our data (Fig. 5) indicating that biogenic Fe has a longer residence time in the upper ocean than lithogenic $\mathrm{Fe}$ which is not accessed by biota. The role of $\mathrm{pFe}$ in supplying bioavailable $\mathrm{Fe}$ is also supported by the similarity of the $\mathrm{pFe}$ and dFe profile shapes in Fig. 3, which infer that pFe may be contributing to the control of $\mathrm{dFe}$, either by supplying it or because biogenic particles are controlling both.

Finally, our estimation of $\mathrm{Fe}$ supply and regeneration allowed us to estimate an $f e$ ratio, defined by Boyd et al. (2005) as $f e=$ uptake of new $\mathrm{Fe} /$ (uptake of new + regenerated $\mathrm{Fe}$ ). For the plume region, $f e$ was 1.4 (Table 1). This was higher than the $f e$ ratio calculated for KEOPS-1 (0.49; Sarthou et al., 2008), which at that time was comparable to the average $f$-ratio for nitrogen of 0.41 (corresponding to $\mathrm{NO}_{3}^{-}$ uptake / $\left(\mathrm{NO}_{3}^{-}\right.$uptake $+\mathrm{NH}_{4}^{+}$uptake); Mosseri et al., 2008), indicating that both $\mathrm{NH}_{4}^{+}$and regenerated $\mathrm{Fe}$ could support export production. Conversely, the KEOPS- $f$-ratio was higher (up to 0.9; Cavagna et al., 2014), indicating that primary production was mainly sustained by nitrate uptake. The $f e$ ratios for both KEOPS studies were much higher than the $f e$ ratio estimated during FeCycle-I (0.17, Boyd et al., 2005) and SAZ-Sense (0.06-0.16; Bowie et al., 2009). This confirms that, in the Kerguelen region, there are sufficient new 

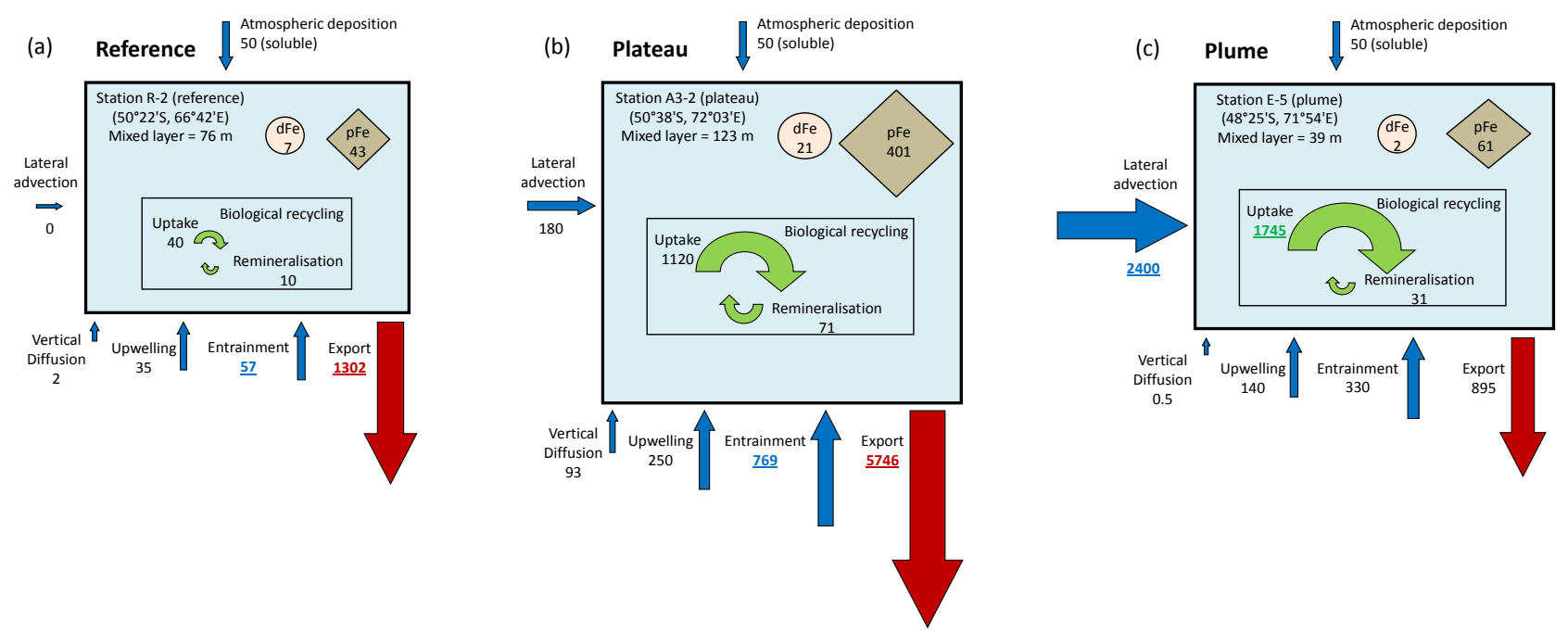

Figure 7. Biogeochemical iron budgets for the reference (R-2, a), plateau (A3-2, b) and plume (E-5, c) stations. Iron pools are given in $\mu \mathrm{mol} \mathrm{m} \mathrm{m}^{-2}$ and iron fluxes in nmol m $\mathrm{m}^{-2} \mathrm{~d}^{-1}$. Iron sources are shown as blue arrows, sinks as red arrows and the green arrows indicate biological Fe cycling. The size of the arrows is roughly proportional to the magnitude of the Fe fluxes, with major fluxes shown as bold underlined text.

sources of Fe delivered on a seasonal timescale (predominantly via intraseasonal entrainment, winter mixing, lateral transport and particulate Fe dissolution) available to sustain the massive bloom observed in spring.

\section{Conclusions}

The complex regional circulation, multiple iron sources, and transport pathways above and downstream of the naturally fertilised Kerguelen Plateau region results in a mosaic of phytoplankton blooms. The budgets presented here result from direct measurements of the Fe inventories and fluxes between different pools. The system was not in steady state during the period of the KEOPS-2 observations, and the exchange of Fe between the dissolved, biogenic and lithogenic pools was highly dynamic in time and space. Our analysis highlights the important role of $\mathrm{pFe}$, the inherent heterogeneity and biogeochemical differences associated with particulates within and exported below the mixed layer and the lithogenic to biogenic conversion pathways.

This study also highlights the significance not only of the mode of Fe fertilisation on the plateau (predominantly vertical) versus the plume (predominantly lateral) but also of the relative magnitude. Importantly, since the Fe supply from new sources to the plume was more than double that above the plateau, this implies that the waters that supply the plume are not the same as those at station A3 on the southern plateau, and the plume must be supplied with water from the northern part of the plateau or Kerguelen coastal waters, which are richer in dFe (Quéroué et al., 2015; Trull et al., 2015). This source of Fe, which will contain a large frac- tion of particulate material (van der Merwe et al., 2015) that is transported off the Kerguelen Plateau, is therefore an important but previously unquantified contribution to the downward flux of Fe exiting the upper ocean in the plume. Moreover, the KEOPS-2 results are tightly linked to the mode of Fe supply that is different from dust deposition or purposeful additions and to the concomitant supply of major nutrients, and this has consequences for the carbon sequestration efficiency of the system. When Fe supply is predominantly vertical (as it is at station A3), then the $\mathrm{C}$ sequestration efficiency is lower (i.e. higher Fe / C) as $\mathrm{C}$ would be resupplied to the mixed layer as well as Fe. This coupling has important implications for geoengineering schemes that propose to increase the supply of Fe to surface waters by pumping waters from below.

Future efforts should focus on the quantification of the full seasonal cycle of Fe delivery, which will be fundamental to closing the iron budget around the Kerguelen Archipelago on annual timescales. This will allow the assessment of the important longer-term climatic and ecosystem implications with changes in the nature and strength of Fe supply with physical (weakening overturning circulation, warming, increased stratification) and chemical (ocean acidification, deoxygenation) environmental forcings, together with increases in glacial melt, rainfall and dust deposition on a warming planet.

The Supplement related to this article is available online at doi:10.5194/bg-12-4421-2015-supplement. 
Author contributions. A. R. Bowie designed the iron budgets, performed the calculations and prepared the manuscript with contributions from all co-authors. P. van der Merwe, F. Quéroué, G. Sarthou, F. Chever and A. T. Townsend collaborated on trace metal sampling, analyses and interpretation; M. Fourquez and I. Obernosterer were responsible for biological cycling, T. Trull for carbon dynamics and the P-trap deployments, F. Planchon for Th-based export and J.B. Sallé for vertical flux estimates. S. Blain designed the overall KEOPS-2 project and helped with budget calculations.

Acknowledgements. We thank the captain B. Lassiette, officers and crew of RV Marion Dufresne, Pierre Sangiardi (Institut PaulÉmile Victor) and the Institut National des Sciences de l'Univers for voyage logistics and their support of the science, and voyage leader Bernard Quéguiner (Institut Méditerranéen d'Océanologie) and chief scientist Stéphane Blain (LOMIC, Université Pierre et Marie Curie) for leading the KEOPS-2 expedition. We acknowledge Thomas Rodemann (UTAS) for CHN analysis in the Central Science Laboratory, together with members of the ISP and P-trap teams for support at sea. Michael Ellwood (Australian National University) kindly loaned the TMR for the project. Access to ICP-MS was provided through Australian Research Council LIEF funds (LE0989539). The altimeter and colour and temperature products for the Kerguelen area were produced by Ssalto/Duacs and CLS with support from CNES and kindly prepared by Emmanuel Laurenceau-Cornec (UTAS) and Francesco d'Ovidio (LOCEAN - IPSL, Université Pierre et Marie Curie). We thank Isabella Rosso (Australian National University) for useful discussion.

This KEOPS-2 project was supported by the French Research program of INSU-CNRS LEFE-CYBER ("Les enveloppes fluides et l'environnement" - "Cycles biogéochimiques, environnement et ressources"), the French ANR ("Agence Nationale de la Recherche", SIMI-6 program, ANR-2010-BLAN-614 KEOPS2 and, ANR-10-JCJC-606 ICOP), the French CNES program ("Centre National d'Etudes Spatiales") and the French Polar Institute IPEV (Institut Polaire Paul-Émile Victor). The Australian participation in the project was supported by the Antarctic Climate and Ecosystems Cooperative Research Centre and a University of Tasmania "Rising Stars" award to the lead author.

We thank two anonymous reviewers for their very constructive comments, which improved our manuscript.

Edited by: B. Quéguiner

\section{References}

Abrajevitch, A., Roberts, A. P., and Kodama, K.: Volcanic iron fertilization of primary productivity at Kerguelen Plateau, Southern Ocean, through the Middle Miocene Climate Transition, Palaeogeogr. Palaeoclimatol. Palaeoecol., 410, 1-13, 2014.

Assmy, P., et al.: Thick-shelled, grazer-protected diatoms decouple ocean carbon and silicon cycles in the iron-limited Antarctic Circumpolar Current, Proc. Natl. Acad. Sci. USA, 110, 2063320638, 2013.

Baker, A. R., Jickells, T. D., Witt, M., and Linge, K. L.: Trends in the solubility of iron, aluminium, manganese and phosphorus in aerosol collected over the Atlantic Ocean, Mar. Chem., 98, 4358, 2006.

Bhattachan, A., D’Odorico, P., Baddock, M. C., Zobeck, T. M., Okin, G. S., and Cassar, N.: The Southern Kalahari: A potential new dust source in the Southern Hemisphere?, Environ. Res. Lett., 7, 1-7, 2012.

Bishop, J. K. B., Lam, P. J., and Wood T. J.: Getting good particles: Accurate sampling of particles by large volume in-situ filtration, Limnol. Oceanogr., 10, 681-710, 2012.

Blain S. et al.: Effect of natural iron fertilization on carbon sequestration in the Southern Ocean, Nature, 446, 1070-1074, 2007.

Blain, S., Quéguiner, B., and Trull, T.: The natural iron fertilization experiment KEOPS (KErguelen Ocean and Plateau compared Study): An overview, Deep Sea Res. II, 55, 559-565, 2008a.

Blain, S., Sarthou, G., and Laan, P.: Distribution of dissolved iron during the natural iron-fertilization experiment KEOPS (Kerguelen Plateau, Southern Ocean), Deep Sea Res. II, 55, 594-605, 2008b.

Blain, S., Capparos, J., Guéneuguès, A., Obernosterer, I., and Oriol, L.: Distributions and stoichiometry of dissolved nitrogen and phosphorus in the iron-fertilized region near Kerguelen (Southern Ocean), Biogeosciences, 12, 623-635, doi:10.5194/bg-12623-2015, 2015.

Borer, P. M., Sulzberger, B., Reichard, P., and Kraemer, S. M.: Effect of siderophores on the light-induced dissolution of colloidal iron(III)(hydr)oxides, Mar. Chem., 93, 179-193, 2005.

Borer, P., Sulzberger, B., Hug, S. J., Kraemer, S. M., and Kretzschmar, R.: Photoreductive dissolution of iron(III) (hydr)oxides in the absence and presence of organic ligands: experimental studies and kinetic modelling, Environ. Sci. Technol., 43, 1864 1870, 2009.

Bowie A. R. and Lohan M. C.: Analysis of Iron in Seawater. Chapter 12 in: "Practical Guidelines for the Analysis of Seawater", edited by: Wurl O., Taylor and Francis, Boca Raton (USA), Chapter 12, ISBN 978-1-4200-7306-5, 235-257, 2009.

Bowie A. R., Maldonado M. T., Frew R. D., Croot P. L., Achterberg E. P., Mantoura R. F. C., Worsfold P. J., Law C. S., and Boyd P. W.: The fate of added iron during a mesoscale fertilisation experiment in the Southern Ocean, Deep Sea Res. II, 48, 2703-2743, 2001.

Bowie A. R., Lannuzel D., Remenyi T. A., Wagener T., Lam P. J., Boyd P. W., Guieu C., Townsend A. T., and Trull T. W.: Biogeochemical iron budgets of the Southern Ocean south of Australia: Decoupling of iron and nutrient cycles in the subantarctic zone by the summertime supply, Glob. Biogeochem. Cy., 23, GB4034, doi:10.1029/2009GB003500, 2009.

Bowie A. R., Townsend A. T., Lannuzel D., Remenyi T., and van der Merwe P.: Modern sampling and analytical methods for the determination of trace elements in marine particulate material using magnetic sector ICP-MS, Anal. Chim. Acta, 676, 15-27, 2010.

Boyd, P. W. and Ellwood, M. J.: The biogeochemical cycle of iron in the ocean, Nat. Geosci., 3, 675-682, doi:10.1038/ngeo964, 2010

Boyd P., et al.: A mesoscale phytoplankton bloom in the polar Southern Ocean stimulated by iron fertilization, Nature, 407 695-702, 2000.

Boyd, P. W. et al.: FeCycle: Attempting an iron biogeochemical budget from a mesoscale SF6 tracer experiment in unperturbed low iron waters, Glob. Biogeochem. Cy., 19, GB4S20, doi:10.1029/2005GB002494, 2005. 
Boyd, P. W., et al.: Mesoscale Iron Enrichment Experiments 19932005: Synthesis and Future Directions, Science, 315, 612-617, 2007.

Breitbarth, E., Achterberg, E. P., Ardelan, M. V., Baker, A. R., Bucciarelli, E., Chever, F., Croot, P. L., Duggen, S., Gledhill, M., Hassellöv, M., Hassler, C., Hoffmann, L. J., Hunter, K. A., Hutchins, D. A., Ingri, J., Jickells, T., Lohan, M. C., Nielsdóttir, M. C., Sarthou, G., Schoemann, V., Trapp, J. M., Turner, D. R., and Ye, Y.: Iron biogeochemistry across marine systems progress from the past decade, Biogeosciences, 7, 1075-1097, doi:10.5194/bg-7-1075-2010, 2010.

Brussaard, C. P. D., Timmermans, K. R. , Uitz, J., and Veldhuis, M. J. W.: Virioplankton dynamics and virally induced phytoplankton lysis versus microzooplankton grazing southeast of the Kerguelen (Southern Ocean), Deep-Sea Res. II, 55, 752-765, 2008.

Carlotti, F., Thibault-Botha, D., Nowaczyk, A., and Lefèvre, D.: Zooplankton community structure, biomass and role in carbon fluxes during the second half of a phytoplankton bloom in the eastern sector of the Kerguelen shelf (January-February 2005), Deep Sea Res. II, 55, 720-733, 2008.

Carlotti, F., Jouandet, M.-P., Nowaczyk, A., Harmelin-Vivien, M., Lefèvre, D., Guillou, G., Zhu, Y., and Zhou, M.: Mesozooplankton structure and functioning during the onset of the Kerguelen phytoplankton bloom during the Keops2 survey, Biogeosciences Discuss., 12, 2381-2427, doi:10.5194/bgd-12-2381-2015, 2015.

Carranza, M. M., and Gille, S. T.: Southern Ocean winddriven entrainment enhances satellite chlorophyll- $a$ through the summer, J. Geophys. Res. Oc., 120, 304-323, doi:10.1002/2014JC010203, 2015.

Cavagna, A. J., Fripiat, F., Elskens, M., Dehairs, F., Mangion, P., Chirurgien, L., Closset, I., Lasbleiz, M., Flores-Leiva, L., Cardinal, D., Leblanc, K., Fernandez, C., Lefèvre, D., Oriol, L., Blain, S., and Quéguiner, B.: Biological productivity regime and associated $\mathrm{N}$ cycling in the vicinity of Kerguelen Island area, Southern Ocean, Biogeosciences Discuss., 11, 18073-18104, doi:10.5194/bgd-11-18073-2014, 2014.

Chever, F., Sarthou, G., Bucciarelli, E., Blain S., and Bowie A. R.: An iron budget during the natural iron fertilization experiment KEOPS (Kerguelen Island, Southern Ocean), Biogeosciences, 7, 455-468, doi:10.5194/bg-7-455-2010, 2010.

Christaki, U., Lefèvre, D., Georges, C., Colombet, J., Catala, P., Courties, C., Sime-Ngando, T., Blain, S., and Obernosterer, I.: Microbial food web dynamics during spring phytoplankton blooms in the naturally iron-fertilized Kerguelen area (Southern Ocean), Biogeosciences, 11, 6739-6753, doi:10.5194/bg-116739-2014, 2014.

Cutter, G. A. and Bruland K. W.: Rapid and noncontaminating sampling system for trace elements in global ocean surveys, Limnol. Oceanogr., 10, 425-436, 2012.

de Baar, H. J. W., de Jong, J. T. M., Bakker, D. C. E., Löscher, B. M., Veth, C., Bathmann, U., and Smetacek, V.: Importance of iron for plankton blooms and carbon dioxide drawdown in the Southern Ocean, Nature, 373, 412-415, 1995.

de Baar, H. J. W. et al.: Synthesis of iron fertilization experiments: From the iron age in the age of enlightenment, J. Geophys. Res., 110, C09S16, doi:10.1029/2004JC002601, 2005.

de Baar, H. J. W. et al.: Efficiency of carbon removal per added iron in ocean iron fertilization, Mar. Ecol. Prog. Ser., 364, 269-282, 2008. de Jong J. T. M. et al.: Dissolved iron at sub-nanomolar levels in the Southern Ocean as determined by ship-board analysis, Anal. Chim. Acta, 377, 113-124, 2008.

de Jong, J., Schoemann, V., Lannuzel, D., Croot, P., de Baar, H., and Tison, J.-L.: Natural iron fertilization of the Atlantic sector of the Southern Ocean by continental shelf sources of the Antarctic Peninsula, J. Geophys. Res., 117, G01029, doi:10.1029/2011JG001679, 2012.

d'Ovidio, F., Della Penna, A., Trull, T. W., Nencioli, F., Pujol, I., Rio, M. H., Park, Y.-H., Cotté, C., Zhou, M., and Blain, S.: The biogeochemical structuring role of horizontal stirring: Lagrangian perspectives on iron delivery downstream of the Kerguelen plateau, Biogeosciences Discuss., 12, 779-814, doi:10.5194/bgd-12-779-2015, 2015.

Dunbar, M. J. (Ed.): Arctic Institution of North America, McGill University, Montreal, 1977.

Ellwood, M. J., Nodder, S. D., Boyd, P. W., King, A. L., Hutchins, D. A., and Wilhelm, S. W.: Pelagic iron cycling during the subtropical spring bloom, east of New Zealand, Mar. Chem., 160, 18-33, 2014.

Fourquez, M., Obernosterer, I., Davies, D. M., Trull, T. W., and Blain, S.: Microbial iron uptake in the naturally fertilized waters in the vicinity of the Kerguelen Islands: phytoplankton-bacteria interactions, Biogeosciences, 12, 1893-1906, doi:10.5194/bg12-1893-2015, 2015.

Frants, M. et al.: Analysis of horizontal and vertical processes contributing to natural iron supply in the mixed layer in southern Drake Passage, Deep Sea Res. II, 90, 68-76, doi:10.1016/j.dsr2.2012.06.001, 2013.

Frew, R. D., Hutchins D. A., Nodder S., Sanudo-Wilhelmy S., Tovar-Sanchez A., Leblanc K., Hare C. E., and Boyd P. W.: Particulate iron dynamics during FeCycle in subantarctic waters southeast of New Zealand, Glob. Biogeochem. Cy., 20, GB1S93, doi:10.1029/2005GB002558, 2006.

Gerringa, L. J. A., Blain, S., Laan, P., Sarthou, G., Veldhuis, M. J. W., Brussaard, C. P. D., Viollier, E., and Timmermans, K. R.: Fe-binding dissolved organic ligands near the Kerguelen Archipelago in the Southern Ocean (Indian sector), Deep Sea Res. II, 55, 606-621, 2008.

Gordon, A. L., Taylor, H. W., and Georgi, D. T.: Antarctic oceanography zonation. In: Proceedings of SCOR/SCAR Polar Oceans Conference, Montreal, Canada, May 5-11, 1974.

Grenier, M., Della Penna, A., and Trull, T. W.: Autonomous profiling float observations of the high-biomass plume downstream of the Kerguelen Plateau in the Southern Ocean, Biogeosciences, 12, 2707-2735, doi:10.5194/bg-12-2707-2015, 2015.

Gunn, B. M., Coyyll, R., Watkins, N. D., Abranson, C. E., and Nougier, J.:, Geochemistry of an oceanite-ankaramite-basalt suite from East Island, Crozet Archipelago, Contrib. Mineral. Petrol., 28, 319-339, 1970.

Heimburger, A., Losno, R., Triquet, S., Dulac, F., and Mahowald, N.: Direct measurements of atmospheric iron, cobalt, and aluminum-derived dust deposition at Kerguelen Islands, Glob. Biogeochem. Cy., 26, GB4016, doi:10.1029/2012GB004301, 2012.

Heimburger, A., Losno, R., Triquet, S., and Bon Nguyen, E.: Atmospheric deposition fluxes of 26 elements over the Southern Indian Ocean: time series on Kerguelen and Crozet Islands, Glob. Biogeochem. Cy., 27, 440-449, 2013a. 
Heimburger, A., Losno, R., and Triquet, S.: Solubility of iron and other trace elements over the Southern Indian Ocean, Biogeosciences, 10, 6617-6628, doi:10.5194/bg-10-6617-2013, 2013b.

Homoky, W. B., John, S. G., Conway, T. M., and Mills, R. A.: Distinct iron isotopic signatures and supply from marine sediment dissolution, Nat. Comm., 4, 2143, doi:10.1038/ncomms3143, 2013

Hudson, R. J. M. and Morel, F. M. M.: Distinguishing between extra- and intracellular iron in marine phytoplankton, Limnol. Oceanogr., 34, 1113-1120, 1989.

Johnson, K. et al.: Developing standards for dissolved iron in seawater, Eos Trans. AGU, 88, 131-132, 2007.

Kieffer, B., Arndt, N. T., and Weis, D.: A Bimodal Alkalic Shield Volcano on Skiff Bank: its Place in the Evolution of the Kerguelen Plateau, J. Petrology, 43, 1259-1286, 2002.

King, P. et al.: Analysis of total and organic carbon and total nitrogen in settling oceanic particles and a marine sediment: an interlaboratory comparison, Mar. Chem., 60, 203-216, 1998.

Lam, P. J. and Bishop, J. K. B.: The continental margin is a key source of iron to the HNLC North Pacific Ocean, Geophys. Res. Lett., 35, L07608, doi:10.1029/2008GL033294, 2008.

Lam, P. J., Bishop, J. K. B., Henning, C. C., Marcus, M. A., Waychunas, G. A., and Fung, I. Y.: Wintertime phytoplankton bloom in the subarctic Pacific supported by continental margin iron, Glob. Biogeochem. Cy., 20, GB1006, doi:10.1029/2005GB002557, 2006.

Lamborg, C. H., Buesseler, K. O., and Lam, P. J.: Sinking fluxes of minor and trace elements in the North Pacific Ocean measured during the VERTIGO program, Deep Sea Res. II, 55, 1564-1577, 2008a.

Lamborg, C. H., Buesseler, K. O., Valdes, J., Bertrand, C. H., Bidigare, R., Manganini, S., Pike, S., Steinberg, D., Trull, T., and Wilson, S.: The flux of bio- and lithogenic material associated with sinking particles in the mesopelagic "Twilight Zone" of the northwest and north central Pacific Ocean, Deep Sea Res. II, 55, 1540-1563, doi:10.1016/j.dsr1012.2008.1004.1011, 2008 b.

Lasbleiz, M., Leblanc, K., Blain, S., Ras, J., Cornet-Barthaux, V., Hélias Nunige, S., and Quéguiner, B.: Pigments, elemental composition $(\mathrm{C}, \mathrm{N}, \mathrm{P}$, and $\mathrm{Si}$ ), and stoichiometry of particulate matter in the naturally iron fertilized region of Kerguelen in the Southern Ocean, Biogeosciences, 11, 5931-5955, doi:10.5194/bg-115931-2014, 2014.

Laurenceau-Cornec, E. C., Trull, T. W., Davies, D. M., Bray, S. G., Doran, J., Planchon, F., Carlotti, F., Jouandet, M.-P., Cavagna, A.-J., Waite, A. M., and Blain, S.: The relative importance of phytoplankton aggregates and zooplankton fecal pellets to carbon export: insights from free-drifting sediment trap deployments in naturally iron-fertilised waters near the Kerguelen Plateau, Biogeosciences, 12, 1007-1027, doi:10.5194/bg-121007-2015, 2015.

Le Moigne F. A. C, Moore C. M., Sanders R. J., Villa-Alfageme M., Steigenberger S., and Achterberg E. P.: Sequestration efficiency in the iron limited North Atlantic: Implications for iron supply mode to fertilized blooms, Geophys. Res. Lett., 41, 4619-4627, 2014.

Mackie, D. S., Peat, J. M., McTainsh, G. H., Boyd, P. W., and Hunter, K. A.: Soil abrasion and eolian dust production: Implications for iron partitioning and solubility, Geochem. Geophys. Geosyst., 7, Q12Q03, doi:10.1029/2006GC001404, 2006.
Mahowald, N. M.: Anthropocene changes in desert area: Sensitivity to climate model predictions, Geophys. Res. Lett., 34, L18817, doi:10.1029/2007GL030472, 2007.

Malits, A., Christaki, U., Obernosterer, I., and Weinbauer, M. G.: Enhanced viral production and virus-mediated mortality of bacterioplankton in a natural iron-fertilized bloom event above the Kerguelen Plateau, Biogeosciences, 11, 6841-6853, doi:10.5194/bg-11-6841-2014, 2014.

Marsay, C. M., Sedwick, P. N., Dinninman, M. S., Barrett, P. M., Mack, S. L., and McGillicuddy Jr., D. J.: Estimating the benthic efflux of dissolved iron on the Ross Sea continental shelf, Geophys. Res. Lett., 41, 7576-7583, doi:10.1002/2014GL061684, 2014.

Martin, J. H.: Glacial-interglacial $\mathrm{CO}_{2}$ change: The iron hypothesis, Paleoceanography, 5, 1-13, 1990.

Measures, C. I., Landing, W. M., Brown, M. T., and Buck, C. S.: High-resolution $\mathrm{Al}$ and $\mathrm{Fe}$ data from the Atlantic Ocean CLIVAR-CO2 Repeat Hydrography A16N transect: extensive linkages between atmospheric dust and upper ocean geochemistry, Glob. Biogeochem. Cy., 22, GB1005, doi:10.1029/2007GB003042, 2008.

Mongin, M., Molina, E., and Trull, T. W.: Seasonality and scale of the Kerguelen plateau phytoplankton bloom: A remote sensing and modeling analysis of the influence of natural iron fertilization in the Southern Ocean, Deep Sea Res. II, 55, 880-892, doi:10.1016/j.dsr2.2007.12.039, 2008.

Moore, C. M., Hickman, A. E., Poulton, A. J., Seeyave, S., and Lucas, M. I.: Iron-light interactions during the CROZet natural iron bloom and EXport experiment (CROZEX) II: taxonomic responses and elemental stoichiometry, Deep Sea Res. II, 54, 2066-2084, 2008.

Moore, J. K. and Doney, S. C.: Iron availability limits the ocean nitrogen inventory stabilizing feedbacks between marine denitrification and nitrogen fixation, Glob. Biogeochem. Cy., 21, GB2001, doi:10.1029/2006GB002762, 2007.

Morris P. J. and Charette M. A.: A synthesis of upper ocean carbon and dissolved iron budgets for Southern Ocean natural iron fertilisation studies, Deep Sea Res. II, 90, 147-157, 2013.

Mosseri, J., Quéguiner, B., Armand, L., and Cornet-Barthaux, V.: Impact of iron on silicon utilization by diatoms in the Southern Ocean: A case study of $\mathrm{Si} / \mathrm{N}$ cycle decoupling in a naturally ironenriched area, Deep Sea Res. II, 55, 801-819, 2008.

Nishioka, J., Ono, T., Saito, H., Sakaoka, K., and Yoshimura, T.: Oceanic iron supply mechanisms which support the spring diatom bloom in the Oyashio region, western subarctic Pacific, J. Geophys. Res., 116, C02021, doi:10.1029/2010JC006321, 2011.

Obata, H., Karatani, H., and Nakayama, E.: Automated determination of iron in seawater by chelating resin concentration and chemiluminescence detection, Anal. Chem., 5, 1524-1528, 1993.

Osborn, T. R.: Estimates of the local rate of vertical diffusion from dissipation measurements, J. Phys. Oceanogr., 10, 83-89, 1980.

Park, Y.-H., Fuda, J.-L., Durand, I., and Naveira Garabato, A.C.: Internal tides and vertical mixing over the Kerguelen Plateau, Deep Sea Res. II, 55, 582-593, 2008a.

Park, Y.-H., Roquet, F., Durand, I., and Fuda, J.-L.: Large-scale circulation over and around the Northern Kerguelen Plateau, Deep Sea Res. II, 55, 566-581, 2008b. 
Park, Y.-H., Durand, I., Kestenare, E., Rougier, G., Zhou, M., d'Ovidio, F., Cotté, C., and Lee, J.-H.: Polar Front around the Kerguelen Islands: An up-to-date determination and associated circulation of surface/subsurface waters, J. Geophys. Res. Oceans, 119, 6575-6592, doi:10.1002/2014JC010061, 2014a.

Park, Y.-H., Lee, J.-H., Durand, I., and Hong, C.-S.: Validation of Thorpe-scale-derived vertical diffusivities against microstructure measurements in the Kerguelen region, Biogeosciences, 11, 6927-6937, doi:10.5194/bg-11-6927-2014, 2014b.

Planchon, F., Ballas, D., Cavagna, A.-J., Bowie, A. R., Davies, D., Trull, T., Laurenceau, E., Van Der Merwe, P., and Dehairs, F.: Carbon export in the naturally iron-fertilized Kerguelen area of the Southern Ocean based on the ${ }^{234} \mathrm{Th}$ approach, Biogeosciences Discuss., 11, 15991-16032, doi:10.5194/bgd11-15991-2014, 2014.

Planchon, F., Ballas, D., Cavagna, A.-J., Bowie, A. R., Davies, D., Trull, T., Laurenceau-Cornec, E. C., Van Der Merwe, P., and Dehairs, F.: Carbon export in the naturally iron-fertilized Kerguelen area of the Southern Ocean based on the 234Th approach, Biogeosciences, 12, 3831-3848, doi:10.5194/bg-12-3831-2015, 2015.

Planquette, H. and Sherrell, R. M.: Sampling for particulate trace element determination usingwater sampling bottles: methodology and comparison to in situ pumps, Limnol. Oceanogr. Methods, 10, 367-388, doi:10.4319/lom.2012.10.367, 2012.

Planquette H. et al.: Dissolved iron in the vicinity of the Crozet Islands, Southern Ocean, Deep Sea Res. II, 54, 1999-2019, 2007.

Planquette H., Fones G. R., Statham P. J., and Morris P. J.: Origin of iron and aluminium in large particles $(>53 \mu \mathrm{m})$ in the Crozet region, Southern Ocean, Mar. Chem., 115, 31-42, 2009.

Planquette, H., Sanders, R. R., Statham, P. J., Morris, P. J., and Fones, G. R.: Fluxes of particulate iron from the upper ocean around the Crozet Islands: A naturally iron-fertilized environment in the Southern Ocean, Glob. Biogeochem. Cy., 25, GB2011, doi:10.1029/2010GB003789, 2011.

Planquette, H., Sherrell R. M., Stammerjohn, S., and Field M. P.: Particulate iron delivery to the water column of the Amundsen Sea, Antarctica, Mar. Chem., 153, 15-30, 2013.

Pollard, R. T. et al.: Southern Ocean deep-water carbon export enhanced by natural iron fertilization, Nature, 457, 577-580, 2009.

Price, N. M. and Morel, F. M. M.: Biological cycling of iron in the ocean. In: "Metal Ions in Biological Systems", Vol. 35, Iron Transport and Storage in Micro-organisms, Plants and Animals, Marcel Dekker, New York, 1-36, 1998.

Prospero, J. M., Ginoux, P., Torres, O., Nicholson, S. E., and Gill, T. E.: Environmental characterization of global sources of atmospheric soil dust identified with the Nimbus 7 Total Ozone Mapping Spectrometer (TOMS) absorbing aerosol product, Rev. Geophys., 40, 1002, doi:10.1029/2000RG000095, 2002.

Quéroué, F., Sarthou, G., Planquette, H. F., Bucciarelli, E., Chever, F., van der Merwe, P., Lannuzel, D., Townsend, A. T., Cheize, M., Blain, S., d'Ovidio, F., and Bowie, A. R.: High variability of dissolved iron concentrations in the vicinity of Kerguelen Island (Southern Ocean), Biogeosciences Discuss., 12, 231-270, doi:10.5194/bgd-12-231-2015, 2015.

Roquet, F., Park, Y.-H., Guinet, C., Bailleul, F., and Charrassin, J.B.: Observations of the Fawn Trough Current over the Kerguelen Plateau from instrumented elephant seals, J. Mar. Sys., 78, 377393, doi:10.1016/j.jmarsys.2008.11.017, 2009.
Rosso, I., et al.: Vertical transport in the ocean due to sub-mesoscale structures: Impacts in the Kerguelen region, Ocean Model., doi:10.1016/j.ocemod.2014.05.001, 2014.

Sanial, V., van Beek, P., Lansard, B., Souhaut, M., Kestenare, E., d'Ovidio, F., Zhou, M., and Blain, S.: Use of Ra isotopes to deduce rapid transfer of sediment-derived inputs off Kerguelen, Biogeosciences, 12, 1415-1430, doi:10.5194/bg-12-1415-2015, 2015.

Sarmiento, J. L. and Gruber, N.: Carbon Cycle, Chapter 8 in: "Ocean Biogeochemical Dynamics", Princeton University Press, Princeton (USA), 318-358, ISBN: 9780691017075, 2006.

Sarthou, G., Baker, A. R., Blain, S., Achterberg, E. P., Boye, M., Bowie, A. R., Croot, P., Laan, P., de Baar, H. J. W., Jickells, T. D., and Worsfold, P. J.: Atmospheric iron deposition and sea-surface dissolved iron concentrations in the eastern Atlantic Ocean, Deep Sea Res. I, 50, 1339-1352, 2003.

Sarthou, G., Vincent, D., Christaki, U., Obernosterer, I., Timmermans, K. R., and Brussaard, C. P. D.: The fate of biogenic iron during a phytoplankton bloom induced by natural fertilisation: Impact of copepod grazing, Deep Sea Res. II, 55, 734, doi:10.1016/j.dsr2.2007.12.033, 2008.

Savoye, N., Trull, T. W., Jacquet, S. H. M., Navez, J., and Dehairs, F.: ${ }^{234}$ Th-based export fluxes during a natural iron fertilization experiment in the Southern Ocean (KEOPS), Deep Sea Res. II, 55, 841, doi:10.1016/j.dsr2.2007.12.036, 2008.

Schlitzer, R.: Carbon export fluxes in the Southern Ocean: results from inverse modelling and comparison with satellite-based estimates, Deep Sea Res. II, 49, 1623-1644, 2002.

Schneider, B., Schlitzer, R., Fischer, G., and Nothig, E.-M.: Depth dependent elemental compositions of particulate organic matter (POM) in the ocean, Glob. Biogeochem. Cy., 17, 1032, doi:10.1029/2002GB001871, 2003.

Schroth, A. W., Crusius, J., Sholkovitz, E. R., and Bostick, B. C.: Iron solubility driven by speciation in dust sources to the ocean, Nat. Geosci. 2, 337-340, 2009.

SCOR Working Group: GEOTRACES - An international study of the global marine biogeochemical cycles of trace elements and their isotopes, Chem. Erde, 67, 85-131, 2007.

Sedwick, P. N., Sholkovitz, E. R., and Church, T. M.: Impact of anthropogenic combustion emissions on the fractional solubility of aerosol iron: Evidence from the Sargasso Sea, Geochem. Geophys. Geosyst., 8, Q10Q06, doi:10.1029/2007GC001586, 2007.

Shaked, Y. and Lis, H.: Disassembling Iron Availability to Phytoplankton. Front, Microbiol, 3, 123, doi:10.3389/fmicb.2012.00123, 2012.

Sherrell, R. M. and Boyle, E. A.: The trace metal composition of suspended particles in the oceanic water column near Bermuda, Earth Planet. Sci. Lett., 111, 155-174, 1992.

Shih, L. H., Koseff, J. R., Ivey, G. N., and Ferziger, J. H.: Parameterization of turbulent fluxes and scales using homogeneous sheared stably stratified turbulence simulations, J. Fluid Mechan., 525, 193-214, 2005.

Sokolov, S. and Rintoul, S. R.: Circumpolar structure and distribution of the Antarctic Circumpolar Current fronts: 1. Mean circumpolar paths, J. Geophys. Res., 114, C11018, doi:10.1029/2008JC005108, 2009.

Strzepek, R. F., Maldonado, M. T., Higgins, J. L., Hall, J., Safi, K., Wilhelm, S. W., and Boyd, P. W.: Spinning the "Ferrous Wheel": the importance of the microbial community in an iron 
budget during the FeCycle experiment, Glob. Biogeochem. Cy., 19, GB4S26, doi:10.1029/2005GB002490, 2005

Sunda, W. G. and Huntsman, S. A.: Iron uptake and growth limitation in oceanic and coastal phytoplankton, Mar. Chem., 50, 189-206, 1995.

Tagliabue, A., Bopp, L., and Aumont, O.: Evaluating the importance of atmospheric and sedimentary iron sources to Southern Ocean biogeochemistry, Geophys. Res. Lett., 36, L13601, doi:10.1029/2009GL038914, 2009.

Tagliabue, A., Sallée, J.-B., Bowie, A. R., Lévy, M., Swart, S., and Boyd, P. W.: Surface-water iron supplies in the Southern Ocean sustained by deep winter mixing, Nat. Geosci., 7, 314320, doi:10.1038/ngeo2101, 2014.

Tang D. G. and Morel F. M. M.: Distinguishing between cellular and Fe-oxide-associated trace elements in phytoplankton, Mar. Chem., 98, 18-30, 2006.

Taylor, S. R. and McLennan, S. M.: The geochemical evolution of the continental crust, Rev. Geophys., 33, 241-265, 1989.

Thuróczy, C.-E., Alderkamp, A.-C.. Laan, P., Gerringa, L. J. A., de Baar, H. J. W., and Arrigo, K. R.: Key role of organic complexation of iron in sustaining phytoplankton blooms in the Pine Island and Amundsen Polynyas (Southern Ocean), DSR II, 71-76, 49-60, 2012.

Tortell, P. D., Maldonado, M. T., and Price, N. M.: The role of heterotrophic bacteria in iron-limited ocean ecosystems, Nature, 383, 330-332, 1996.

Trull, T. W., Davies, D., and Casciotti, K.: Insights into nutrient assimilation and export in naturally iron-fertilized waters of the Southern Ocean from nitrogen, carbon and oxygen isotopes, Deep Sea Res. II, 55, 820-840, 2008.

Trull, T. W., Davies, D. M., Dehairs, F., Cavagna, A.-J., Lasbleiz, M., Laurenceau-Cornec, E. C., d'Ovidio, F., Planchon, F., Leblanc, K., Quéguiner, B., and Blain, S.: Chemometric perspectives on plankton community responses to natural iron fertilisation over and downstream of the Kerguelen Plateau in the Southern Ocean, Biogeosciences, 12, 1029-1056, doi:10.5194/bg-121029-2015, 2015.
Twining, B. S., Baines, S. B., Fisher, N. S., and Landry M. R.: Cellular iron contents of plankton during the Southern Ocean Iron Experiment (SOFeX), Deep Sea Res. I, 51, 1827- 1850, 2004.

van Beek, P., Bourquin, M., Reyss, J. L., Souhaut, M., Charette, M. A., and Jeandel, C.: Radium isotopes to investigate the water mass pathways on the Kerguelen Plateau (Southern Ocean), Deep Sea Res. II, 55, 622-637, 2008.

van der Merwe, P., Bowie, A. R., Quéroué, F., Armand, L., Blain, S., Chever, F., Davies, D., Dehairs, F., Planchon, F., Sarthou, G., Townsend, A. T., and Trull, T. W.: Sourcing the iron in the naturally fertilised bloom around the Kerguelen Plateau: particulate trace metal dynamics, Biogeosciences, 12, 739-755, doi:10.5194/bg-12-739-2015, 2015.

Wadley, M. R., Jickells, T. D., and Heywood, K. J.: The role of iron sources and transport for Southern Ocean productivity, Deep Sea Res. I, 87, 82-94, 2014.

Wagener, T., Guieu, C., Losno, R., Bonnet, S., and Mahowald, N.: Revisiting atmospheric dust export to the southern hemisphere ocean: biogeochemical implication, Glob. Biogeochem. Cy., 22, GB2006, doi:10.1029/2007GB002984, 2008.

Wedepohl, K. H.: The composition of the continental crust, Geochim. Cosmochim. Acta, 59, 1217-1232, 1995.

Westberry, T. K., Behrenfeld, M. J., Milligan, A. J., and Doney, S. C.: Retrospective satellite ocean color analysis of purposeful and natural ocean iron fertilization, Deep Sea Res. I, 73, 1-16, 2013.

Zhang, Y., Lacan, F., and Jeandel, C.: Dissolved rare earth elements tracing lithogenic inputs over the Kerguelen Plateau (Southern Ocean), Deep Sea Res. II, 55, 638-652, 2008.

Zhou, M., Zhu, Y., Dorland, R. D., and Measures, C. I.: Dynamics of the current system in the southern Drake Passage, Deep Sea Res. I, 57, 1039-1048, 2010.

Zhou, M., Zhu, Y., d'Ovidio, F., Park, Y.-H., Durand, I., Kestenare, E., Sanial, V., Van-Beek, P., Quéguiner, B., Carlotti, F., and Blain, S.: Surface currents and upwelling in Kerguelen Plateau regions, Biogeosciences Discuss., 11, 6845-6876, doi:10.5194/bgd-116845-2014, 2014. 